BADAN PENDIDIKAN DAN PELATIHAN KEUANGAN KEMENTERIAN KEUANGAN REPUBLIK INDONESIA

\title{
PERAN PEMANTAUAN DAN EVALUASI UNTUK MENINGKATKAN EFISIENSI DAN EFEKTIFITAS PELAKSANAAN PROYEK/KEGIATAN YANG DIBIAYAI MELALUI PINJAMAN
}

\author{
Yanuar Pribadi \\ Direktorat Evaluasi, Akuntansi dan Setelmen, Direktorat Jenderal Pengelolaan Pembiayaan dan Risiko, \\ Kementerian Keuangan, Email: y.pribadi@kemenkeu.go.id
}

\section{INFO ARTIKEL}

SEJARAH ARTIKEL

09 Juli 2019

Dinyatakan Dapat Dimuat 31 Desember 2019

\section{KATA KUNCI:}

Pemantauan,

Evaluasi,

Progress Variant.

Pinjaman Pemerintah

\begin{abstract}
ABSTRAK
Peran Pemantauan dan Evaluasi Untuk Meningkatkan Efisiensi dan Efektifitas Pelaksanaan Proyek/Kegiatan Yang Dibiayai Melalui Pinjaman. Pemantauan dan evaluasi bertujuan untuk memastikan pelaksanaan suatu program telah sesuai dengan rencana untuk mencapai tujuan yang ditetapkan. Sumber pembiayaan yang berasal dari utang menimbulkan konsekuensi berupa biaya yang harus ditanggung dalam pelaksanaan proyek/kegiatan tersebut. Pemantauan dan evaluasi yang tidak efektif berisiko menimbulkan tambahan biaya pinjaman yang dapat membebani keuangan negara. Kementerian Keuangan sebagai pengelola utang negara melakukan pemantauan dan evaluasi pada aspek keuangan berupa realisasi penarikan dan menilai kinerja suatu proyek/kegiatan menggunakan metode Progress Variant. Penelitian ini bertujuan untuk mengetahui peranan pemantauan dan evaluasi dalam meningkatkan efisiensi dan efektifitas pelaksanaan proyek/kegiatan, sekaligus mengidentifikasi permasalahan yang memengaruhi pelaksanaan proyek/kegiatan yang dibiayai melalui pinjaman. Hasil penelitian menunjukkan bahwa pemantauan dan evaluas belum dapat meningkatkan efisiensi dan efektifitas pelaksanaan proyek/kegiatan yang dibiayai melalui pinjaman. Permasalahan pelaksanaan proyek terjadi karena koordinasi antar instansi yang kurang baik, dan pelaksana kegiatan yang tidak dapat memenuhi persyaratan penarikan yang ditetapkan oleh pemberi pinjaman. Oleh karena itu, penyempurnaan proses pemantauan dan evaluasi diperlukan untuk meningkatkan efisiensi dan efektifitas pelaksanaan proyek sehingga dapat meminimalkan biaya pinjaman.
\end{abstract}

The Role of Monitoring and Evaluation in Improving the Efficiency and Effectiveness of the Project Implementation Funded using Government Loans. Monitoring and evaluation aims to ensure the program implementation in accordance with the program goals achievement plan. The ineffective monitoring and evaluation of debt financing has negative consequences that the additional borrowing costs arise in the project implementation, which is burden the government finances. The Ministry of Finance as the administrative unit of government debt management is monitoring and evaluating the financial aspects in the form of evaluating the project performance through the Progress Variant method. This study aims to determine the role of monitoring and evaluation in improving the efficiency and effectiveness of project implementation, and identifying problems that affect the implementation of projects financed through loans. The study result shows that monitoring and evaluation of government loans are insufficient to improve the project efficiency and effectiveness. There are some issues in project implementation such as poor coordination between agencies, implementing agency unable to comply the disbursement standards from lender. Refinement of monitoring and evaluation process is needed to increasing project effectiveness and efficiency to minimize the borrowing costs.

\section{PENDAHULUAN}

\subsection{Latar Belakang}

Pemantauan dan Evaluasi merupakan tahapan penting dalam siklus perencanaan dan pelaksanaan suatu kegiatan. Pemantauan dilakukan agar semua data atau informasi dari suatu kegiatan yang diamati dapat menjadi landasan dalam mengambil keputusan dan melakukan tindakan yang dibutuhkan. Tindakan tersebut merupakan respon atas hasil pengamatan yang menunjukkan hasil yang tidak sesuai dengan rencana yang telah ditetapkan. Evaluasi bertujuan untuk melihat tingkat keberhasilan pengelolaan kegiatan, melalui penilaian terhadap manajemen dan output pelaksanaan serta permasalahan yang dihadapi. Hasil penilaian tersebut selanjutnya menjadi 
bahan evaluasi kinerja program dan kegiatan selanjutnya.

Pembiayaan anggaran melalui utang merupakan strategi pemerintah untuk mengatasi keterbatasan sumber dana dalam Anggaran Pendapatan dan Belanja Negara (APBN). Salah satu bentuk pembiayaan anggaran tersebut ialah pendanaan proyek/kegiatan melalui pinjaman. Sumber pembiayaan proyek/ kegiatan melalui pinjaman tentu memiliki konsekuensi berupa beban yang harus ditanggung oleh pemerintah baik berupa pembayaran pokok, bunga, maupun biaya. Oleh karena itu, Kementerian/ Lembaga sebagai pelaksana proyek/kegiatan, Kementerian Keuangan sebagai pengelola keuangan negara, dan Bappenas selaku unit perencana pembangunan harus memastikan bahwa pelaksanaan proyek/kegiatan tersebut dilakukan dengan efektif dan efisien serta memberikan manfaat kepada masyarakat.

Ruang lingkup pemantauan dan evaluasi yang dilakukan oleh Kementerian Keuangan terhadap pelaksanaan proyek/kegiatan yang dibiayai melalui pinjaman ialah pemantauan dari sisi aspek keuangan. Aspek keuangan ini mencakup realisasi penarikan pinjaman yang dilakukan oleh Kementerian/Lembaga pelaksana proyek. Penyerapan atau realisasi penarikan pinjaman tersebut menjadi ukuran untuk menilai kinerja pelaksanaan proyek/kegiatan. Kendala pada pelaksanaan proyek/kegiatan yang terjadi dapat memengaruhi kinerja penyerapan atau realisasi penarikan pinjaman dan mengakibatkan keterlambatan pelaksanaan proyek/kegiatan serta menimbulkan potensi penambahan biaya yang harus ditanggung oleh pemerintah.

Tulisan ini membahas mengenai peran pemantauan dan evaluasi untuk meningkatkan efisiensi, efektifitas dan meminimalkan biaya pendanaan proyek/kegiatan yang dibiayai pinjaman. Penelitian dilakukan untuk menjawab pertanyaan apakah pemantauan dan evaluasi dapat meningkatkan efisiensi dan efektifitas pelaksanaan proyek/kegiatan yang dibiayai melalui pinjaman yang dilakukan oleh Kementerian Keuangan, sekaligus mengidentifikasi permasalahan yang memengaruhi kinerja pelaksanaan proyek/kegiatan yang dibiayai melalui pinjaman. Bagian pertama berisi studi literatur tentang konsep, pendekatan, metode, serta proses pemantauan dan evaluasi serta konsep pemantauan berbasis hasil. Bagian kedua membahas pelaksanaan pemantauan dan evaluasi proyek/kegiatan yang dibiayai melalui pinjaman yang dilakukan oleh Direktorat Jenderal Pengelolaan Pembiayaan dan Risiko (DJPPR), Kementerian Keuangan. Bagian ketiga mengetengahkan permasalahan yang terjadi dalam proses pemantauan dan evaluasi, serta alternatif pengembangan pemantauan dan evaluasi proyek/ kegiatan yang dibiayai melalui pinjaman.

\section{KERANGKA TEORITIS}

\subsection{Konsep Pemantauan dan Evaluasi}

Definisi pemantauan mencakup: 1) Kegiatan yang mengamati perkembangan pelaksanaan rencana pembangunan, identifikasi dan antisipasi permasalahan yang akan timbul untuk dapat diambil tindakan intervensi sedini mungkin; 2) Kegiatan yang berkesinambungan menggunakan pengumpulan data yang sistematis dari indikator yang spesifik, untuk memberikan informasi bagi stakeholder tentang kemajuan pencapaian tujuan dari penggunaan anggaran yang dialokasikan (DAC-OECD, 2010). Sementara itu, definisi Evaluasi adalah suatu proses menentukan nilai atau pentingnya suatu kegiatan kebijakan, atau program. Evaluasi merupakan sebuah penilaian yang obyektif dan sistematis terhadap sebuah kegiatan yang direncanakan, sedang berlangsung atau pun yang telah diselesaikan. Objek yang harus dievaluasi antara lain yaitu proyek, program, kebijakan, organisasi, sektor, tematik, dan bantuan negara (DAC-OECD, 2010).

Evaluasi adalah sebuah penilaian, intervensi yang sedang berjalan atau sudah selesai untuk melihat revelansi, ketepatgunaan (efisiensi), efektivitas, dampak dan keberlangsungan dari suatu proses perencanaan. Tujuannya adalah untuk memasukkan pelajaran yang didapat (feedback) ke dalam proses pengambilan keputusan. Evaluasi berguna untuk memberikan informasi yang valid tentang kinerja kebijakan, program dan kegiatan. Selain itu, dapat memberikan masukan untuk menjawab klarifikasi dan kritik terhadap nilai-nilai yang mendasari pemilihan tujuan dan target, serta digunakan untuk melihat peluang adanya alternatif kebijakan, program, kegiatan yang lebih tepat, layak, efektif, efisien. Lebih jauh lagi, evaluasi berguna untuk memberikan umpan balik terhadap kebijakan, program dan proyek, dan menjadi sarana pertanggungjawaban pelaksanaan dan penggunaan dana suatu kebijakan, program dan proyek.

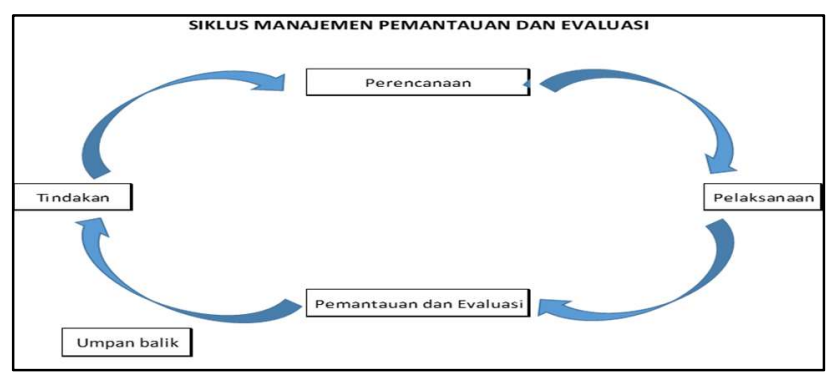

Gambar 1 Siklus Manajemen Pemantauan dan Evaluasi

\subsection{Pendekatan, Metode, dan Proses Pemantauan dan Evaluasi}

Beberapa pendekatan evaluasi dasar yang dapat digunakan untuk mengukur tingkat keberhasilan implementasi program antara lain: before and after comparisons; with and without comparisons; actualversus-planned performance comparisons; experimental (controlled) models; quasi-experimental 
models; dan cost-oriented approaches (Patton, Sawicki dan Clark, 2013).

Dari beberapa pendekatan tersebut, Costoriented approaches memberikan solusi atas kondisi yang mengharuskan mengukur dampak kebijakan dalam satuan uang, estimasi biaya dan keuntungan bersih dari perubahan berupa penyimpangan pelaksanaan program, mengukur keuntungan yang terlihat maupun tidak terlihat, serta biaya yang harus dikeluarkan baik secara langsung berupa uang, maupun tidak langsung berupa dampak buruk yang akan dirasakan kedepannya.

Cost-oriented approaches ini terdiri atas 2 tipe utama, yakni: 1) Analisis keuntungan biaya (cost benefit analysis): membandingkan outcome terhadap input dan dinyatakan dalam nilai uang. Seperti pengembalian investasi, nilai bersih dari pengeluaran dan keuntungan pelaksanaan program, dan keuntungan terhadap rasio pengeluaran. 2) Analisis keefektifan biaya (cost-effectiveness analysis): mengidentifikasi upaya pencapaian tujuan program atau kebijakan dengan biaya seminimal mungkin. Melalui analisis ini, pelaksanaan program yang berbeda diukur berdasarkan biaya yang dihabiskan dalam mencapai tujuan program.

Pendekatan-pendekatan mengenai evaluasi tersebut merupakan alternatif yang dapat dilakukan oleh pihak-pihak yang terkait untuk menilai tingkat keberhasilan suatu program atau kegiatan. Dalam melakukan pemantauan dan evaluasi, Kaufman dan Thomas mengemukakan 8 (delapan) model monitoring dan evaluasi program, yaitu: Goal-oriented Evaluation Model; Goal-free Evaluation Model; Formative-Summative Evaluation Model; Countenance Evaluation Model; Responsive Evaluation Model; CIPP Evaluation Model; CSE-UCLA Evaluation Model; Discrepancy Evaluation Model (DEM) (Arikunto dan Jabar, 2010)

Metode pemantauan dan evaluasi yang lebih sederhana dikenal dengan indikator SMART (Muktiali, 2009), yakni: Specific, tujuan yang hendak diukur harus secara khusus menggambarkan hal-hal yang diinginkan; Measurable, tujuan yang hendak diukur harus dapat dijabarkan dalam indikator yang terukur; Attainable, tujuan yang hendak diukur harus dapat dicapai dengan kondisi sumber daya dan potensi yang ada; Relevant, tujuan yang hendak diukur harus relevan dengan kebutuhan informasi dan pengelolaan yang ada; serta Timely, tujuan yang hendak diukur harus tepat waktu dalam arti kondisi yang diperlukan dan kebutuhan yang berkembang.

Proses yang terdapat dalam kegiatan pemantauan dan evaluasi secara sederhana ialah "menelusuri" proses pekerjaan proyek/kegiatan sehingga dapat menemukan "apa yang sesungguhnya terjadi" antara pelaksanaan (proses) dan tujuan yang dirumuskan. Apabila dalam penelusuran atau pemantauan itu ditemukan penyimpangan maka segera diambil langkah-langkah rekomendasi perbaikan sehingga kesenjangan bisa segera teratasi, atau setidaknya meminimalisir kerugian yang muncul.

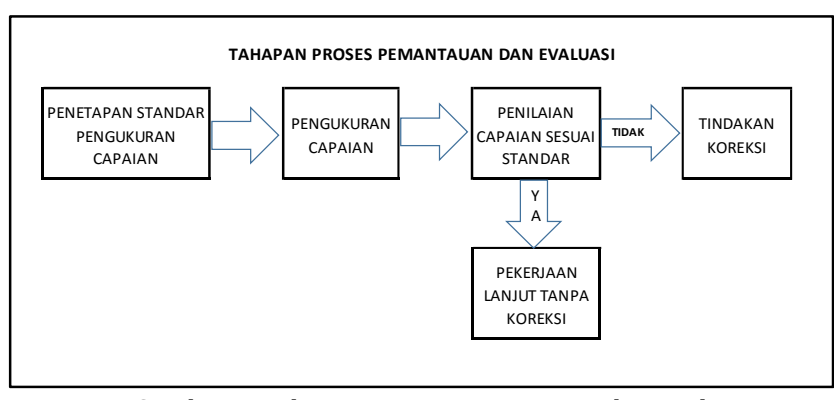

Gambar 2. Tahapan Proses Pemantauan dan Evaluasi

\subsection{Pemantauan Berbasis Hasil}

Sistem pemantauan berbasis hasil merupakan suatu sistem pemantauan yang dilakukan secara menyeluruh mulai dari masukan, pelaksanaan program, keluaran sampai dengan outcome dan dampak atas suatu program. Sistem pemantauan berbasis hasil berbeda dengan sistem pemantauan tradisional karena pemantauan yang bersifat tradisional hanya sampai pada keluaran (output) atas suatu program tersebut.

Tahapan-tahapan dalam penyusunan sistem pemantauan berbasis hasil antara lain: penilaian tentang kesiapan program; penetapan outcome sebagai dasar pemantauan dan evaluasi; pemilihan indikator kunci untuk memantau outcome, sesuai prinsip CREAM (Clear, Relevant Economics, Adequate, Monitorable); penetapan Baseline dan pengumpulan data tentang indikator; perencanaan peningkatan kualitas hasil sasaran; pemantauan hasil; proses evaluasi; pelaporan hasil temuan; penggunaan hasil temuan (tindak lanjut rekomendasi); dan sistem pemantauan dan evaluasi yang berkelanjutan di dalam organisasi.

Periodisasi pelaksanaan evaluasi dikategorikan menjadi tiga tahapan yaitu: Tahap Perencanaan (ex ante), dilakukan sebelum ditetapkannya suatu program, untuk melihat rasionalitas pilihan, target dan kesesuaian antar dokumen perencanaan; Tahap Pelaksanaan (on-going), dilakukan saat pelaksanaan kegiatan, untuk menjamin kegiatan dilakukan sesuai dengan rencana yang telah ditetapkan; dan, Tahap Pasca-Pelaksanaan (ex post), dilakukan setelah pelaksanaan program berakhir, bertujuan untuk menilai pencapaian (keluaran/hasil/dampak) program, mampu mengatasi masalah yang ingin diselesaikan dengan program tersebut, serta untuk menilai efisiensi, efektivitas dan dampak terhadap sasaran, ataupun manfaat dari suatu program.

\section{METODOLOGI PENELITIAN}

Metodologi yang digunakan dalam penelitian ini ialah metode analisis kualitatif deskriptif. Penelitian kualitatif merupakan metode untuk mengeksplorasi dan memahami makna yang berasal dari masalah sosial atau kemanusiaan (Cresswell, 2014), 
menganalisis pengalaman orang-orang melalui wawancara, focus group discussion, observasi atau melalui cara lainnya sehingga peneliti dapat mengidentifikasi topik permasalahan dari perspektif para partisipan serta memahami makna dan interpretasi mereka terhadap perilaku, kejadian atau objek tertentu (Hennink, Hutter, Bailey, 2011). Prinsip pokok analisis data kualitatif ialah mengolah dan menganalisis data yang terkumpul menjadi data yang sistematis, teratur, terstruktur dan mempunyai makna, sehingga dapat digunakan untuk menjawab masalah yang dirumuskan dalam penelitian. Analisis deskriptif merupakan suatu metode melalui serangkaian kegiatan studi literatur dengan menelaah teori, informasi, dan data, baik yang berasal dari buku, publikasi ilmiah, peraturan perundangan maupun informasi lain yang relevan.

Analisis kualitatif deskriptif dilakukan terhadap pelaksanaan pemantauan dan evaluasi yang dilakukan untuk mengidentifikasi permasalahan yang timbul dan memengaruhi kinerja pelaksanaan proyek/ kegiatan yang dibiayai pinjaman. Permasalahan tersebut dapat berasal dari internal Kementerian Keuangan, Kementerian/Lembaga selaku pelaksana proyek/kegiatan bahkan dari pemberi pinjaman.

Penulis melakukan kegiatan observasi rapat pemantauan pelaksanaan proyek untuk mengumpulkan informasi dari Kementerian/Lembaga selaku pelaksana proyek, Bappenas, dan Kementerian Keuangan. Penulis juga menganalisis data sekunder berupa dokumen penarikan pinjaman dari lender, serta pembayaran commitment fee. pinjaman yang mengalami keterlambatan (berstatus behind schedule dan at risk) kemudian membandingkannya dengan commitment fee yang seharusnya dibayar jika proyek-proyek tersebut tepat waktu, sehingga ditemukan potensi efisiensi pembayaran commitment fee jika proyek berjalan tepat waktu. Sampel data yang dianalisis ialah data pembayaran commitment fee yang dilakukan oleh DJPPR, Kementerian Keuangan mulai saat pinjaman tersebut ditandatangani sampai dengan periode bulan Juni 2019. Hasil analisis terhadap sampel data pembayaran commitment fee menunjukkan bahwa terdapat potensi tambahan pembayaran biaya yang disebabkan oleh keterlambatan pelaksanaan proyek. Potensi tambahan biaya ini bisa diminimalkan apabila proyek berjalan secara tepat waktu (Lampiran 2).

\section{HASIL DAN PEMBAHASAN}

4.1. Pemantauan dan Evaluasi Proyek/Kegiatan yang Dibiayai Melalui Pinjaman di Kementerian Keuangan

Pinjaman merupakan salah satu sumber pendanaan proyek/kegiatan yang dilaksanakan oleh Kementerian/Lembaga teknis sebagai pelaksana (Executing Agency). Ketentuan mengenai Tata cara pengadaan pinjaman diatur dalam Peraturan Pemerintah (PP) Nomor 10 Tahun 2011 tentang Tata
Cara Pengadaan Pinjaman Luar Negeri dan Penerimaan Hibah dan PP Nomor 54 Tahun 2008 tentang Tata Cara Pengadaan dan Penerusan Pinjaman Dalam Negeri Oleh Pemerintah. Ketentuan mengenai pemantauan dan evaluasi proyek kegiatan yang dibiayai melalui pinjaman diatur lebih lanjut melalui Peraturan Menteri Keuangan (PMK) Nomor 224/PMK.08/2011 tentang Tata Cara Pemantauan dan Evaluasi atas Pinjaman dan Hibah kepada Pemerintah, sebagaimana terakhir diubah dengan PMK Nomor 180/PMK.08/2012.

Mekanisme pemantauan dan evaluasi proyek/kegiatan yang dibiayai pinjaman dilakukan dengan cara penyampaian laporan secara triwulanan oleh K/L, Pemda dan BUMN selaku Executing Agency kepada Kementerian Keuangan dan Bappenas. Laporan triwulanan tersebut minimal memuat mengenai: pelaksanaan pengadaan barang/jasa, kemajuan fisik kegiatan, realisasi penyerapan, permasalahan dalam pelaksanaan, serta rencana tindak lanjut penyelesaian masalah. Pasal 77 ayat (1) PP Nomor 10 Tahun 2011 menyatakan bahwa Menteri Keuangan melakukan pemantauan, evaluasi, dan pelaporan triwulanan mengenai realisasi penyerapan Pinjaman Luar Negeri dan/atau Hibah dan aspek keuangan lainnya (lihat Lampiran 3).

Ketentuan pemantauan dan evaluasi pada PMK Nomor 224/PMK.08/2011 menyebutkan bahwa ruang lingkup pemantauan yang dilakukan oleh Kementerian Keuangan mencakup: 1) Disbursement plan atas perjanjian Pinjaman dan/atau Hibah yang masih berstatus aktif dan perjanjian Pinjaman dan/atau Hibah baru dalam rangka memenuhi kebutuhan APBN berjalan; 2) Pemenuhan condition precedents of effectiveness Pinjaman dan/atau Hibah termasuk persyaratan biaya Pinjaman dan realisasi pembayarannya; 3) Amandemen perjanjian Pinjaman dan/atau Hibah; 4) Restrukturisasi Pinjaman termasuk rescheduling, prepayment, debt swap dan skema restrukturisasi lainnya; 5) Rencana penarikan dana Pinjaman dan/atau Hibah yang dialokasikan dalam (Daftar Isian Pelaksanaan Anggaran (DIPA) tahun berjalan; 6) Realisasi pencairan dana Pinjaman dan/atau Hibah yang ditunjukkan di dalam dokumen Surat Perintah Pencairan Dana (SP2D), Withdrawal Application (WA), Surat Perintah Pembukuan/ Pengesahan (SP3), Nota disposisi (Nodis) dan dokumen sejenis lainnya; dan 7) Realisasi pencairan dana dari pemberi Pinjaman dan/atau Hibah yang tercermin dalam Notice of Disbursement (NOD) atau dokumen sejenis lainnya.

Sumber data yang digunakan sebagai pendukung pemantauan berasal dari: 1) Basis data Debt Management and Financial Analysis System (DMFAS); 2) Laporan triwulanan yang diterima dari Kementerian/Lembaga, Pemda, dan BUMN selaku Executing Agency; 3) Hasil rapat berkala dan ad hoc dengan K/L, Pemda dan BUMN selaku Executing 
Agency; atau 4) Dokumen atau sumber-sumber lain yang relevan.

Evaluasi terhadap proyek/kegiatan yang dibiayai pinjaman dilakukan dengan melakukan pengujian konsistensi data perencanaan anggaran dan realisasi. Pengujian tersebut dilakukan dengan cara: 1) Membandingkan antara rencana penarikan dana dengan alokasi dana dalam DIPA; 2) Membandingkan antara alokasi Pinjaman dan/atau Hibah dalam DIPA dengan realisasi pencairan dana Pinjaman dan/atau Hibah berupa SP2D, WA, Nodis, dan SP3; 3) Membandingkan antara WA serta SP3 dari KPPN Khusus dengan realisasi NOD atau dokumen lain yang dipersamakan dari pemberi Pinjaman dan/atau Hibah; dan 4) Mengukur atau membandingkan antara capaian pelaksanaan kegiatan yang sedang berjalan dengan menggunakan teknik perhitungan Progress Variant.

Progress Variant adalah rasio yang diperoleh dari perbandingan antara persentase penarikan pinjaman yang telah dilakukan (disbursement ratio) dengan persentase waktu terpakai (elapsed time ratio) dari pinjaman yang bersangkutan.

Disbursement ratio adalah perbandingan antara realisasi penarikan pinjaman dengan komitmen nilai bersihnya. Sedangkan Elapsed time ratio didefinisikan sebagai perbandingan antara periode yang telah dilampaui mulai effective date dengan periode penarikan pinjaman (availability period).

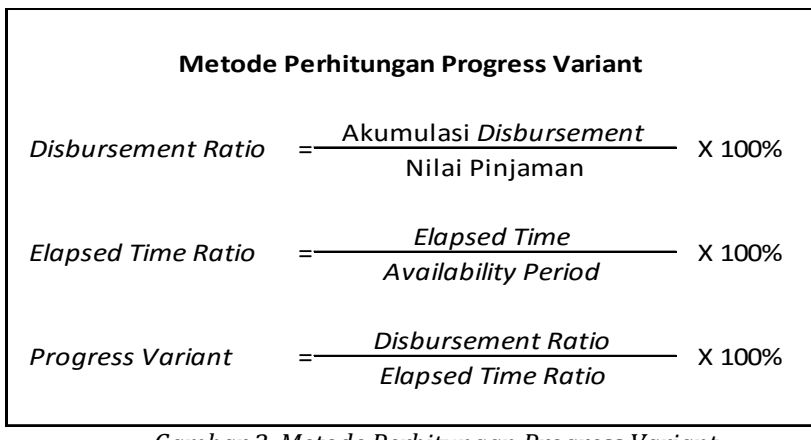

Gambar 3. Metode Perhitungan Progress Variant

Perhitungan Progress Variant tersebut akan menghasilkan tiga kategori kinerja proyek yaitu:

a) PV >= 1 (on and above schedule), yang berarti realisasi penarikan pinjaman telah sesuai atau lebih cepat dari jadwal yang direncanakan;

b) $0,3<\mathrm{PV}<1$ (behind schedule), yang berarti realisasi penarikan pinjaman lebih lambat dari jadwal yang direncanakan;

c) $\mathrm{PV}=<0,3$ (at risk), yang berarti realisasi penarikan pinjaman mengalami keterlambatan yang akut sehingga berisiko memunculkan biaya tambahan yang harus ditanggung APBN.

Perhitungan Progress Variant yang dilakukan terhadap pinjaman yang belum ditarik (zero disbursed) menghasilkan kategori kinerja proyek sebagai berikut: a) Kategori behind schedule, apabila elapsed time ratio $=<70 \%$ dari availability period;

b) Kategori at risk, apabila elapsed time ratio $>70 \%$ dari availability period.

Hasil pemantauan dan evaluasi yang dilakukan oleh Kementerian Keuangan tersebut disampaikan dalam bentuk laporan pemantauan secara berkala untuk memberikan gambaran mengenai realisasi penyerapan kegiatan yang dibiayai pinjaman selama satu triwulan berjalan, memberikan informasi mengenai status pelaksanaan kegiatan, mengidentifikasi permasalahan, sehingga dapat digunakan untuk mengambil langkah-langkah tindak lanjut untuk mengatasi permasalahan proyek/kegiatan tersebut.

\subsection{Permasalahan Dalam Proses Pelaksanaan Pemantauan dan Evaluasi Proyek/Kegiatan yang Dibiayai Melalui Pinjaman}

Proses pemantauan dan evaluasi proyek/kegiatan yang dibiayai melalui pinjaman dilakukan oleh Kementerian Keuangan dengan cara menilai kinerja pelaksanaan proyek/kegiatan dari aspek keuangan berupa realisasi penarikan pinjaman. Pemantauan dan evaluasi tersebut dilakukan terhadap pinjaman yang berstatus "active".

Pemantauan dan evaluasi dilakukan dengan tujuan untuk meminimalkan biaya pinjaman, sehingga pembiayaan proyek/kegiatan yang dibiayai dari pinjaman dapat dilakukan secara efektif dan efisien. Pemantauan dan evaluasi pinjaman yang tidak berjalan dengan baik akan berdampak pada peningkatan biaya pinjaman berupa tambahan pengenaan biaya seperti commitment fee, insurance premium dan biaya-biaya lainnya. Elaborasi mengenai potensi risiko penambahan biaya pinjaman karena keterlambatan pelaksanaan proyek/kegiatan dapat dilihat di Lampiran II.

\subsubsection{Pemantauan dan Evaluasi masih Bersifat Parsial}

Pemantauan dan evaluasi proyek/kegiatan yang dibiayai melalui pinjaman dilakukan oleh tiga pihak, yaitu Kementerian/Lembaga teknis yang berperan sebagai pelaksana proyek, Kementerian Keuangan, dan Bappenas. Sebagaimana telah disebutkan sebelumnya, pemantauan dan evaluasi yang dilakukan oleh Kementerian Keuangan ialah pemantauan dan evaluasi pada aspek keuangan yaitu berupa realisasi penarikan pinjaman.

Realisasi penarikan pinjaman diakui oleh Kementerian Keuangan sebagai pihak yang berperan menjadi administrative unit pinjaman yang dilakukan oleh Pemerintah melalui pencatatan dokumen penarikan/NOD yang disampaikan oleh pemberi pinjaman. Oleh karena itu, basis data yang digunakan oleh Kementerian Keuangan sebagai dokumen pendukung pemantauan dan evaluasi berasal dari pencatatan realisasi penarikan pinjaman. 
Pihak internal Kementerian Keuangan yang terkait dengan proyek/kegiatan yang dibiayai pinjaman diantaranya ialah: Direktorat Jenderal Anggaran (DJA), Direktorat Jenderal Perbendaharaan (DJPb), Inspektorat Jenderal (Itjen), dan Direktorat Jenderal Pengelolaan Pembiayaan dan Risiko (DJPPR). Dalam hal ini DJA berperan dalam perencanaan anggaran (penyusunan DIPA), DJPb berperan dalam pelaksanaan anggaran (pencairan dana melalui KPPN), sedangkan Itjen berperan melakukan reviu dalam proses penganggaran Bagian Anggaran Bendahara Umum Negara (BA-BUN) Pengelolaan Utang.

Pemantauan di lingkup internal DJPPR dilakukan oleh Direktorat Pinjaman dan Hibah (PH) dan Direktorat Evaluasi, Akuntansi dan Setelmen (EAS). Direktorat PH melakukan pemantauan dari sisi pelaksanaan/realisasi anggaran yang direncanakan di DIPA, sedangkan Direktorat EAS melakukan pemantauan berdasarkan realisasi penarikan (NOD) yang telah dicatat pada DMFAS. Dalam hal ini, terkesan bahwa terdapat tumpang tindih (redundancy) pemantauan yang dilakukan oleh DJPPR yang dilakukan oleh Direktorat PH dan Direktorat EAS. Hal ini berisiko menyebabkan pemantauan yang dilakukan menjadi kurang efektif dan efisien, karena dilakukan oleh pihak yang berbeda dalam satu unit yang sama, dan data yang digunakan sebagai alat pendukung pemantauan pun berbeda. Akibatnya, risiko perbedaan dalam pencatatan realisasi penarikan pinjaman menjadi lebih besar untuk terjadi. Selain itu, terdapat juga pemantauan yang dilakukan oleh Itjen dalam rangka pengelolaan dan pelaksanaan anggaran BA-BUN.

Pemantauan dan evaluasi merupakan satu kesatuan yang diperlukan dalam proses pengelolaan dan pelaksanaan suatu program, sehingga pelaksanaan program tersebut dapat dilakukan sesuai rencana dan mencapai tujuan yang ditetapkan. Berkaitan dengan pemantauan terhadap proyek/kegiatan yang dibiayai melalui pinjaman, perlu batasan yang jelas mengenai pemantauan yang dilakukan sehingga pemantauan dan evaluasi tidak terkesan dilakukan secara terpisah-pisah atau bersifat parsial.

\subsubsection{Ketidaktepatan Penentuan Kriteria Pemantauan dan Evaluasi}

Pemantauan dan evaluasi yang dilakukan oleh DJPPR menggunakan kriteria penilaian berupa Progress Variant untuk menilai kinerja pelaksanaan proyek/kegiatan yang dibiayai melalui pinjaman. Hasil penilaian Progress Variant ini akan menghasilkan proyek yang berkategori on and ahead schedule, behind schedule, dan at risk.

Sebagaimana telah disebutkan sebelumnya bahwa penghitungan Progress Variant diperoleh dari perbandingan antara disbursement ratio dengan elapsed time ratio. Elapsed time ratio merupakan persentase waktu yang telah terpakai setelah pinjaman dinyatakan efektif. Di sisi lain, proyek/kegiatan yang dibiayai pinjaman terutama yang bersifat konstruksi/pembangunan, baru mulai efektif setelah kontrak pelaksanaan pekerjaan pembangunan ditandatangani. Dalam hal ini, terdapat perbedaan dasar penetapan perhitungan jangka waktu Progress Variant dengan jangka waktu riil proyek yang sebenarnya, sehingga perbedaan ini tidak fair jika digunakan untuk membandingkan antara jangka waktu pinjaman dengan jangka waktu pelaksanaan proyek yang sebenarnya.

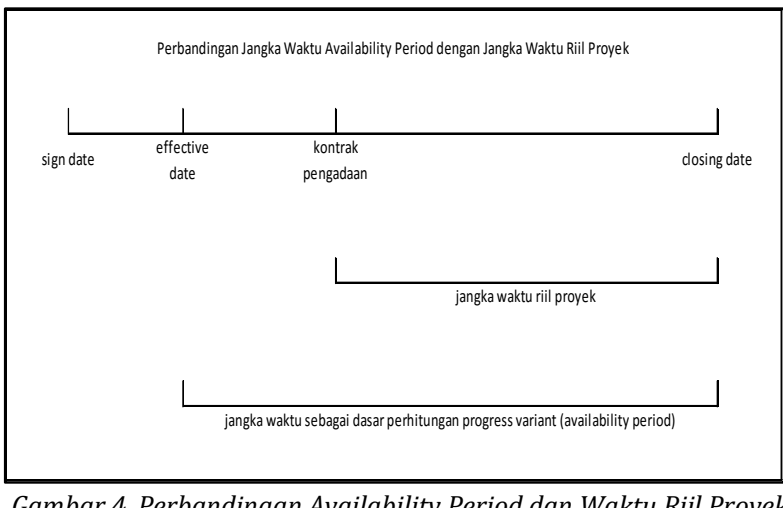

Gambar di atas menunjukkan bahwa perhitungan Progress Variant terhadap proyek/kegiatan yang dibiayai melalui pinjaman tidak dilakukan secara fair karena jangka waktu yang digunakan berbeda. Dengan demikian, metode perhitungan Progress Variant kurang dapat menggambarkan kondisi kemajuan proyek yang sebenarnya.

Perhitungan Progress Variant juga kurang tepat jika diterapkan untuk proyek/kegiatan yang bersifat kontrak pembelian barang (purchase contract). Kontrak pembelian barang misalnya pembelian kapal atau pesawat terbang secara umum baru akan dibayarkan jika barang yang dibeli tersebut sudah tersedia/sudah selesai dan diserahkan kepada pembeli. Sementara itu, pada saat proses pembuatan/perakitan, pihak ketiga atau rekanan belum dapat mengajukan pembayaran sehingga secara otomatis tidak terdapat realisasi penarikan pinjaman. Akibatnya penarikan pinjaman dilakukan terlambat pada akhir periode atau pada saat serah terima barang telah selesai dilakukan. Hal ini akan sangat berpengaruh pada status kinerja pelaksanaan proyek/kegiatan karena keterlambatan penarikan pinjaman tersebut pasti akan membuat proyek/kegiatan tersebut berstatus behind schedule bahkan at risk.

Kekurangan lain dari metode Progress Variant ialah bahwa metode ini membutuhkan proyeksi perhitungan rencana penarikan yang valid dan akurat agar dapat efektif digunakan untuk menilai kinerja pelaksanaan proyek/kegiatan. Fakta di lapangan, saat ini disbursement plan yang disampaikan oleh pelaksana proyek/kegiatan sangat tidak akurat dan 
sebatas hanya digunakan untuk memenuhi persyaratan pada dokumen perencanaan. Tidak efektifnya sisi perencanaan ini tentu berpengaruh pada pelaksanaan proyek/kegiatan karena kurang dapat digunakan sebagai alat evaluasi sebagai pendukung perencanaan selanjutnya.

Pada saat proyek/kegiatan sedang berjalan dan terdapat kecenderungan bahwa proyek/kegiatan tersebut tidak selesai tepat waktu, maka pelaksana proyek/kegiatan dapat mengajukan perpanjangan batas penarikan (closing date) atau mengajukan pembatalan terhadap sebagian nilai komitmen pinjaman (partial cancellation). Penambahan batas waktu penarikan atau pembatalan terhadap sebagian nilai komitmen pinjaman dapat langsung mengubah status proyek karena berubahnya variabel waktu maupun nilai komitmen pinjaman tersebut.

\subsubsection{Keterbatasan Sumber Daya dan Kualitas Pelaksanaan Pemantauan dan Evaluasi}

Peraturan mengenai pelaporan pelaksanaan proyek/kegiatan yang dibiayai melalui pinjaman mensyaratkan agar pelaksana proyek melakukan pemantauan dan melaporkan hasil pemantauan tersebut secara periodik kepada Kementerian Keuangan dan Bappenas. Laporan tersebut berisi perkembangan proses pengadaan barang dan/atau jasa, kinerja pelaksanaan fisik kegiatan, perkembangan realisasi penyerapan dana, perkembangan pencapaian indikator masukan (input) dan keluaran (output), permasalahan yang dihadapi, dan tindak lanjut yang diperlukan. Selain itu, pada akhir pelaksanaan proyek/kegiatan, pelaksana proyek juga harus menyampaikan laporan pasca-kegiatan yang meliputi evaluasi terhadap output, dampak, kesinambungan, dan indikator keberhasilan lainnya.

Pelaksanaan pemantauan dan evaluasi oleh pelaksana proyek/kegiatan seharusnya menjadi langkah awal proses pemantauan secara menyeluruh sehingga kinerja pelaksanaan proyek dapat benarbenar terpampang secara nyata dan hasilnya dapat memberikan nilai tambah sebagai bahan evaluasi dan perencanaan selanjutnya. Akan tetapi, kenyataan yang terjadi di lapangan, pelaksana proyek/kegiatan masih belum sepenuhnya memahami arti penting pemantauan dan evaluasi sehingga masih banyak pelaksana proyek/kegiatan yang tidak menyampaikan laporan atau jika menyampaikan, laporan tersebut tidak menggambarkan fakta detail, lengkap dan akurat serta terkesan hanya untuk memenuhi rutinitas sehingga tidak dapat digunakan sebagai bahan evaluasi sebagai masukan untuk perencanaan selanjutnya. Pihak pelaksana proyek/kegiatan masih beranggapan bahwa kegiatan pemantauan, evaluasi, dan pelaporan adalah kegiatan yang menyita waktu namun kurang memberikan manfaat bagi mereka. Dalam hal ini, kualifikasi sumber daya manusia pelaksana proyek/kegiatan masih perlu ditingkatkan sehingga pelaksana proyek dapat memahami ketentuan pelaksanaan proyek/kegiatan yang dibiayai dari pinjaman.

Di sisi lain, dari sekitar 230 pinjaman yang masih active, sumber daya yang dimiliki oleh unit yang bertugas melakukan pemantauan dan evaluasi di DJPPR (Dit. EAS) sangat terbatas sehingga tidak memungkinkan untuk melakukan pemantauan secara menyeluruh dan komprehensif. Konsekuensinya, pelaksanaan pemantauan dan evaluasi saat ini hanya difokuskan untuk proyek/kegiatan yang bersifat behind schedule dan at risk.

Kelemahan-kelemahan yang terjadi pada proses pemantauan dan evaluasi sebagaimana diungkapkan di atas membuat pemantauan dan evaluasi kurang dapat menjalankan fungsinya untuk menjamin pelaksanaan proyek/kegiatan sesuai dengan rencana yang ditetapkan. Keterlambatan pelaksanaan proyek/kegiatan tersebut berdampak pada munculnya tambahan biaya berupa commitment fee yang harus dibayar oleh pemerintah. Commitment fee ini dibebankan terhadap pinjaman yang belum ditarik sehingga semakin lama pelaksanaan suatu proyek/ kegiatan, maka semakin berpotensi menambah beban biaya commitment fee yang harus dibayar pemerintah.

Data yang diteliti merupakan data pinjaman luar negeri yang dipantau dan dievaluasi oleh Kementerian Keuangan. Pada akhir bulan Juni 2019, terdapat 161 pinjaman luar negeri dengan batas akhir penarikan lebih dari atau sama dengan 2019. Kemudian dihitung elapsed time ratio dan disbursement ratio untuk mendapatkan nilai progress variant-nya. Dari 161 pinjaman tersebut, terdapat 128 pinjaman dengan status behind schedule dan at risk yang tersebar pada 16 Kementerian/Lembaga pelaksana proyek/ kegiatan. Data pinjaman luar negeri aktif dapat dilihat pada Lampiran I.

Untuk mengetahui bagaimana pemantauan dan evaluasi dapat berkontribusi dalam meminimalkan biaya pinjaman, penulis mengambil beberapa contoh proyek/kegiatan yang mengalami keterlambatan (berstatus behind schedule dan at risk). Pinjaman yang dijadikan sampel perhitungan ialah pinjaman dari 5 (lima) Kementerian/Lembaga yang berbeda yaitu: Kementerian Pekerjaan Umum dan Perumahan Rakyat, Kementerian Riset, Teknologi dan Pendidikan Tinggi, Kementerian Pertahanan, Kepolisian Negara RI, dan PT. PLN (Persero). Penulis membandingkan antara commitment fee yang telah dibayar oleh pemerintah dengan nilai commitment fee jika proyek/kegiatan tersebut dilaksanakan secara tepat waktu. Selisih antara pembayaran commitment fee tersebut merupakan tambahan biaya atau biaya yang seharusnya dapat diefisiensi. Contoh perhitungan tambahan biaya (commitment fee) dapat dilihat pada Lampiran II. 


\subsection{Pengembangan Pemantauan dan Evaluasi Proyek/Kegiatan yang Dibiayai Melalui Pinjaman}

Permasalahan yang terjadi dalam proses pemantauan dan evaluasi proyek/kegiatan yang dibiayai melalui pinjaman menunjukkan bahwa masih terdapat kekurangan dalam mekanisme pemantauan dan evaluasi yang selama ini dilakukan. Oleh karena itu, diperlukan langkah-langkah untuk memperbaiki sistem pemantauan dan evaluasi untuk memperbaiki kinerja pelaksanaan proyek/kegiatan dan pada akhirnya berdampak pada meningkatnya efektivitas dan efisiensi pembiayaan anggaran melalui pinjaman.

\subsubsection{Integrasi Sistem Pemantauan dan Evaluasi}

Pemantauan dan evaluasi merupakan satu kesatuan yang diperlukan dalam proses pengelolaan dan pelaksanaan suatu program. Keberhasilan pelaksanaan suatu program tersebut dapat dinilai dari pencapaian tujuan yang ditetapkan. Peran pemantauan dan evaluasi dalam hal ini adalah sebagai alat untuk menilai apakah pelaksanaan suatu program tersebut telah berjalan sesuai rencana atau justru melenceng keluar dari jalur yang telah ditetapkan. Secara umum, pemantauan bertujuan untuk mengukur capaian keberhasilan suatu program berupa keluaran (output), sedangkan evaluasi bertujuan mengukur dampak dari pelaksanaan program tersebut (outcome dan impact).

Tumpang tindih pelaksanaan pemantauan dan evaluasi proyek/kegiatan yang dibiayai melalui pinjaman mengakibatkan sistem pemantauan dan evaluasi menjadi kurang efektif dan efisien. Penentuan batas kewenangan pelaksanaan pemantauan dan evaluasi perlu dilakukan secara tegas sehingga pelaksanaan pemantauan dapat lebih terintegrasi dan terkoordinasi.

Pemantauan terhadap proyek/kegiatan yang dibiayai melalui pinjaman harus sudah dilakukan mulai dari proses perencanaan untuk memastikan kesiapan Kementerian/Lembaga pelaksana proyek. Hal ini untuk mengantisipasi risiko kegagalan pelaksanaan proyek karena beberapa persyaratan yang belum terpenuhi. Integrasi proses perencanaan baik berupa perencanaan kegiatan yang dilakukan oleh Bappenas maupun perencanaan pinjaman yang dilakukan oleh Direktorat PH, DJPPR diperlukan untuk meningkatkan kualitas perencanaan. Perencanaan merupakan titik krusial karena menentukan tonggak keberhasilan suatu program. Dalam konteks proyek/kegiatan yang dibiayai melalui pinjaman, sisi perencanaan proyek ini berada pada Direktorat PH sebagai unit yang bertugas menyiapkan dan merencanakan tahapan-tahapan pelaksanaan proyek sampai dengan perjanjian pinjaman ditandatangani. Setelah proses perencanaan, tahap pelaksanaan proyek menjadi bagian tugas Direktorat EAS sebagai unit yang bertugas melakukan pemantauan dan evaluasi. Pembagian tugas dan kewenangan yang jelas ini diharapkan dapat meningkatkan integrasi dan koordinasi pelaksanaan pemantauan dan evaluasi sehingga pemantauan dan evaluasi dapat dilakukan secara efektif dan efisien. Selain itu, pemisahan kewenangan ini juga dapat menjadi mekanisme check and balance dalam proses perencanaan, pelaksanaan sampai dengan evaluasi program secara menyeluruh Secara ringkas, untuk meningkatkan efisiensi dan efektifitas pelaksanaan pemantauan dan evaluasi, maka pemantauan perlu dilakukan sejak tahap perencanaan proyek/kegiatan (ex ante), tahap pelaksanaan proyek/kegiatan (on going), maupun setelah proyek/kegiatan selesai dilaksanakan (ex post).

Pelaksanaan pemantauan dan evaluasi yang dilakukan oleh masing-masing unit di DJPPR yang dilakukan selama ini meningkatkan risiko kesalahan informasi dan pengulangan pemantauan terhadap proyek/kegiatan yang sama dalam kurun waktu yang relatif tidak begitu jauh. Mekanisme pemantauan secara bersama dapat menjadi satu alternatif untuk mengatasi tumpang tindih pemantauan dan evaluasi sehingga kegiatan tersebut dapat dilakukan dengan lebih terkoordinasi, terarah, dan terintegrasi.

\subsubsection{Penetapan Kriteria Pemantauan Sebagai Baseline dalam Proses Pemantauan dan Evaluasi}

Tahap awal dalam proses pemantauan ialah penetapan standar pelaksanaan. Penetapan standar dilakukan untuk menentukan kriteria sebagai alat untuk mengukur pelaksanaan program. Penentuan kriteria pemantauan ini harus jelas batasan dan definisinya dengan cara mengidentifikasi variabel yang akan dipantau. Progress Variant merupakan alat yang digunakan oleh Kementerian Keuangan untuk menilai kinerja pelaksanaan proyek/kegiatan yang dibiayai melalui pinjaman. Akan tetapi, beberapa kekurangan yang muncul dalam pengaplikasian Progress Variant sebagai kriteria penilaian kinerja proyek tersebut di atas menyebabkan kurang akuratnya penilaian terhadap suatu proyek/kegiatan karena kinerja proyek tersebut tidak dapat dinilai secarai fair sesuai dengan performa yang sebenarnya.

Sebagaimana dibahas pada permasalahan di atas, jangka waktu pelaksanaan pinjaman tidak dapat dibandingkan secara lurus dengan jangka waktu pelaksanaan proyek karena waktunya tidak seimbang. Sehingga perhitungan Progress Variant yang dihitung dari tanggal efektif pinjaman pasti akan mengalami keterlambatan dari jadwal karena harus menunggu proses pengadaan barang/jasa. Di lain pihak, penarikan pinjaman terutama untuk pinjaman yang berkarakteristik pembelian barang (purchase contract) pasti akan lebih banyak terjadi di akhir periode pinjaman karena menunggu serah terima barang, sehingga dalam hal ini metode perhitungan Progress Variant tidak relevan untuk diterapkan pada semua jenis pinjaman. 
Pemantauan dan evaluasi berbasis hasil idealnya mensyaratkan adanya kriteria pengukuran dan evaluasi. Kriteria tersebut ditetapkan di awal pelaksanaan program dan kemudian dinilai dengan cara membandingkan kriteria tersebut dengan realisasi pelaksanaan yang terjadi selama waktu pelaksanaan program. Sebagai alternatif metode perhitungan Progress Variant, pada saat awal periode pelaksanaan proyek/kegiatan, perlu ditetapkan rencana penarikan yang akan dilakukan oleh pelaksana proyek/kegiatan. Rencana penarikan dana ini disusun dengan teliti dan benar-benar memperhatikan perkiraan pelaksanaan proyek/ kegiatan. Secara periodik, rencana penarikan dana yang ditetapkan tersebut akan dibandingkan dengan realisasi penarikan dana pada setiap periode yang bersangkutan. Dengan demikian, pengukuran kinerja pelaksanaan proyek/kegiatan akan lebih tepat sasaran karena membandingkan antara rencana dengan realisasi penarikan dana. Jadi, pada saat awal pelaksanaan proyek/kegiatan, pelaksana proyek menetapkan rencana penarikan dana proyek. Rencana penarikan dana ini dijadikan sebagai dasar perhitungan Progress Variant yang menjadi acuan dalam menilai kinerja pelaksanaan proyek atau dapat disebut sebagai Baseline, untuk kemudian dijadikan sebagai dasar dalam mengukur kinerja pelaksanaan proyek/kegiatan secara keseluruhan.

Setelah Baseline ditetapkan, realisasi penarikan dana dievaluasi dan dibandingkan dengan Baseline tersebut sehingga diperoleh selisih (gap) antara nilai kinerja Baseline dengan nilai kinerja pelaksanaan proyek yang sebenarnya. Gap itulah yang menjadi dasar penilaian apakah pelaksanaan proyek/kegiatan telah sesuai dengan jadwal atau mengalami keterlambatan. Dengan mekanisme ini, pelaksana proyek/kegiatan secara tidak langsung juga harus memperbaiki mekanisme perencanaan mereka sehingga rencana penarikan dana yang disampaikan benar-benar disusun dengan akurat karena akan menjadi dasar bagi penilaian kinerja pelaksanaan proyek/kegiatan yang dilaksanakan. Dengan demikian, penambahan kriteria pemantauan dan evaluasi ini juga menimbulkan konsekuensi berupa perbaikan pada sisi perencanaan pelaksanaan proyek/kegiatan.

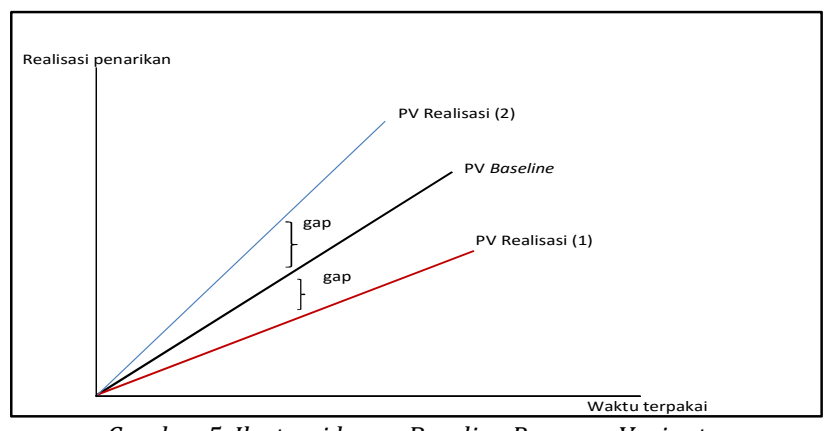

Gambar 5. Ilustrasi kurva Baseline Progress Variant

Kurva PV Baseline merupakan kurva yang diukur menggunakan rencana penarikan (disbursement plan) yang disusun oleh pelaksana proyek/kegiatan dan disampaikan kepada Kementerian Keuangan pada awal pelaksanaan proyek.

Kurva PV realisasi 1 (area di bawah kurva PV Baseline) merupakan kurva yang menggambarkan kinerja yang diukur dari realisasi pelaksanaan proyek dan mengindikasikan adanya keterlambatan pelaksanaan proyek. Selisih (gap) antara PV realisasi 1 dengan PV Baseline dibatasi dalam persentase tertentu (misalnya 0.3) untuk mengklasifikasikan keterlambatan yang masih dapat ditoleransi (behind schedule) atau keterlambatan akut yang berisiko dapat menambah biaya pinjaman (at risk).

Kurva PV realisasi 2 (area di atas kurva PV Baseline) merupakan kurva yang menggambarkan kinerja yang diukur dari realisasi pelaksanaan proyek dan menunjukkan bahwa kemajuan pelaksanaan proyek telah sesuai dengan atau lebih cepat dari yang direncanakan dan mengklasifikasikan pinjaman dalam kategori on and ahead schedule.

\subsubsection{Peningkatan Kapasitas Sumber Daya Pemantauan dan Evaluasi}

Rendahnya kualifikasi sumber daya pengelola proyek memberikan kontribusi yang cukup besar terhadap kualitas pengelolaan proyek secara keseluruhan. Peningkatan kapasitas sumber daya pemantauan dan evaluasi mutlak diperlukan untuk meningkatkan kualitas pelaksanaan proyek. Apabila pelaksana proyek/kegiatan memiliki kesadaran dan pemahaman akan arti penting pemantauan dan evaluasi sebagai bahan perencanaan selanjutnya, maka kualitas pemantauan dan evaluasi juga akan meningkat. Kualifikasi sumber daya manusia yang baik pada akhirnya akan meningkatkan kualitas pengelolaan proyek/kegiatan yang akan bermuara pada meningkatnya efisiensi dan efektifitas pelaksanaan proyek. Selain dalam bentuk peningkatan kualitas sumber daya manusia pelaksana proyek, dapat juga diterapkan kualifikasi minimal yang dibutuhkan oleh setiap pegawai yang akan memegang tanggung jawab pelaksanaan dan pengelolaan proyek/kegiatan yang dibiayai melalui pinjaman.

Penyederhanaan proses bisnis pemantauan, evaluasi, dan pelaporan juga diperlukan untuk mempersingkat waktu dan mendukung proses dan mekanisme pemantauan dan evaluasi. Mekanisme pemantauan dan evaluasi yang terkesan rumit dan menyita waktu membuat para pihak terkait kurang memberikan perhatian yang baik dan hanya sekedar memenuhi kewajiban rutinitas pelaporan. Sistem pemantauan dan evaluasi yang sederhana, mudah, dan cepat perlu dibangun misalnya menggunakan aplikasi berbasis web dalam bentuk pemantauan dan evaluasi secara elektronik.

Pengembangan aplikasi yang terintegrasi akan lebih memudahkan para pihak terkait baik pelaksana proyek, Bappenas, maupun Kementerian Keuangan 
dalam melakukan pemantauan, evaluasi, dan pelaporan. Selain dapat memberikan kemudahan dalam penyampaian laporan, penggunaan teknologi dalam pelaporan pemantauan dan evaluasi dapat menghemat biaya yang timbul dalam rangka pelaksanaan pemantauan dan evaluasi, penyajian dan kemudahan akses data secara realtime, sehingga $\mathrm{K} / \mathrm{L}$ selaku pengelola proyek/kegiatan, Kementerian Keuangan, maupun Bappenas dapat mengambil langkah penyelesaian dengan segera dan tepat sasaran terhadap permasalahan yang memengaruhi keterlambatan pelaksanaan proyek/kegiatan yang dibiayai melalui pinjaman.

Penggunaan teknologi informasi di satu sisi tentu menimbulkan konsekuensi berupa biaya investasi untuk membangun sistem aplikasi, serta risiko kegagalan dalam melakukan pengelolaan data, baik dari sisi keamanan data maupun ketersediaan data dalam suatu basis data yang kompleks. Akan tetapi, dengan adanya perbaikan kualitas sumber daya manusia melalui peningkatan kualifikasi dan kompetensi, dipadukan dengan penyederhanaan proses bisnis dan didukung penerapan teknologi dalam proses pemantauan dan evaluasi, hal tersebut diharapkan dapat memperbaiki proses pemantauan dan evaluasi dan berdampak pada meningkatnya efisiensi dan efektifitas pelaksanaan kegiatan yang dibiayai melalui pinjaman.

\section{KESIMPULAN}

Pemantauan dan evaluasi merupakan satu kesatuan yang diperlukan dalam proses pengelolaan dan pelaksanaan suatu program untuk memastikan pelaksanaan program tersebut telah sesuai dengan rencana dalam rangka mencapai tujuan yang ditetapkan. Salah satu tujuan pemantauan dan evaluasi terhadap proyek/kegiatan yang dibiayai pinjaman ialah meminimalkan biaya pinjaman, sehingga pembiayaan proyek/kegiatan tersebut dilakukan secara efektif dan efisien. Pemantauan dan evaluasi ini dilakukan oleh Kementerian Keuangan pada aspek keuangan yaitu berupa realisasi penarikan pinjaman dengan menggunakan kriteria perhitungan Progress Variant untuk mengukur kinerja pelaksanaan proyek/kegiatan.

Hasil penelitian menunjukkan bahwa pemantauan dan evaluasi yang dilakukan terhadap proyek/ kegiatan yang dibiayai melalui pinjaman masih belum dapat meningkatkan efisiensi dan efektifitas pelaksanaan proyek/kegiatan. Kendala yang terjadi di lapangan antara lain permasalahan pembebasan lahan, proses pengadaan/lelang yang membutuhkan waktu, dan lemahnya koordinasi antara pelaksana proyek di daerah dengan instansi kementerian di pusat belum dapat diselesaikan dengan sistem pemantauan dan evaluasi yang berjalan selama ini. Hal itu menimbulkan risiko berupa potensi adanya tambahan biaya yang menjadi beban keuangan negara.
Biaya yang harus ditanggung pemerintah dapat berupa penambahan biaya komitmen (commitment fee atau insurance premium), atau biaya administrasi dalam rangka perpanjangan masa laku pinjaman (administration fee). Perpanjangan masa laku pinjaman (availability period) karena keterlambatan pelaksanaan proyek/kegiatan juga dapat dianggap sebagai biaya jika tidak diikuti perpanjangan waktu pengembalian pinjaman (repayment period) karena menyebabkan suatu pinjaman menjadi semakin mahal mengingat pinjaman harus dikembalikan dalam waktu yang lebih cepat dari jadwal semula.

Pemisahan dan pembatasan tugas yang jelas dalam proses pemantauan dan evaluasi pada masingmasing unit di DJPPR dibutuhkan untuk menghindari pemantauan yang tumpang tindih dan terpisah terhadap proyek/kegiatan yang sama. Dalam hal ini, pemantauan harus sudah dilakukan mulai dari proses perencanaan untuk memastikan kesiapan Kementerian/Lembaga pelaksana proyek, sedangkan pelaksanaan sampai penyelesaian proyek dilakukan oleh unit evaluasi untuk menilai kinerja pelaksanaan proyek/kegiatan.

Pemantauan yang ideal dilakukan dengan cara menentukan kriteria pemantauan sebagai alat untuk mengukur pelaksanaan program. Batasan dan definisi dalam penentuan kriteria pemantauan ini harus jelas dengan cara mengidentifikasi variabel yang akan dipantau. Penentuan Progress Variant Baseline (PV Baseline) dapat menjadi alternatif untuk menyempurnakan pengukuran kinerja pelaksanaan proyek. Baseline ini diperoleh dari rencana penarikan dana yang ditetapkan oleh pelaksana proyek pada tahap perencanaan. Pengukuran kinerja dilakukan secara periodik dengan cara menghitung selisih (gap) antara rencana dengan realisasi sehingga dapat diketahui tingkat pelaksanaan proyek tersebut sudah sesuai rencana, terlambat atau bahkan mengalami keterlambatan yang akut dan berpotensi menambah biaya pinjaman. Penetapan kriteria Baseline ini dapat memaksa pelaksana proyek untuk meningkatkan akurasi dan memperbaiki sisi perencanaan mereka sehingga proyek/kegiatan yang dibiayai melalui pinjaman benar-benar dikelola dengan profesional. Selain itu, penetapan kriteria Baseline juga lebih tepat dan dapat digunakan sebagai alternatif solusi dalam pelaksanaan pemantauan dan evaluasi pinjaman yang menggunakan mekanisme Purchase Contract.

Keterbatasan pemahaman yang dimiliki oleh sumber daya pelaksana proyek mengenai urgensi pemantauan dan evaluasi sebagai bahan masukan dalam perencanaan selanjutnya harus dikurangi melalui peningkatan kualitas sumber daya pemantauan. Kualifikasi minimal sebagai pengelola proyek/kegiatan juga diperlukan untuk menjamin pengelolaan dan pelaksanaan proyek dilakukan dengan baik. Mekanisme pemantauan, evaluasi, dan pelaporan yang rumit dan menyita waktu dan membuat kualitas pemantauan dan evaluasi yang 
dilakukan tidak akurat dapat dihindari melalui penyederhanaan proses bisnis dan mekanisme pemantauan dan evaluasi. Pembangunan aplikasi pemantauan dan evaluasi berbasis web secara elektronik dapat menjadi alternatif untuk mempersingkat waktu dan biaya sehingga pemantauan dan evaluasi dapat dilakukan secara lebih efektif dan efisien.

\section{IMPLIKASI DAN KETERBATASAN}

Penelitian ini dilakukan secara kualitatif dan terbatas pada data-data internal Kementerian Keuangan sebagai pengelola pinjaman berupa laporan pelaksanaan proyek/kegiatan yang dibiayai melalui pinjaman, data realisasi penarikan pinjaman dan pembayaran commitment fee hingga periode akhir bulan Juni 2019. Meskipun didukung dengan sampel data kinerja pelaksanaan proyek baik berasal dari Kementerian/Lembaga selaku executing agency, maupun Bappenas selaku unit yang bertanggungjawab dalam hal perencanaan pembangunan, cakupan penelitian yang lebih luas misalnya melibatkan pemberi pinjaman (lender) dapat memberikan sudut pandang yang lebih beragam mengenai penyebab permasalahan dalam pengelolaan, pemantauan dan evaluasi proyek/ kegiatan yang dibiayai melalui pinjaman.

\section{DAFTAR REFERENSI}

Arikunto, Suharsimi dan Cepi Safrudin Abdul Jabar. 2010. Evaluasi Program Pendidikan - Edisi Kedua. Jakarta: Bumi Aksara

Creswell, John W. 2014. Research Design: Qualitative, Quantitative and Mixed Methods Approaches, 4th Edition. California: SAGE Publication, Inc.

Development Assistance Committee-Organization for Economic Cooperation and Development (DAC/OECD). 2010. Glossary of Key Terms in Evaluation and Results Based Management. Paris: OECD.

Development Assistance Committee-Organization for Economic Cooperation and Development (DAC/OECD). 1991. Principles for Evaluation of Development Assistance. Paris: OECD.

European Commission Civil Society Fund in Ethiopia. 2017. Introduction to Monitoring and Evaluation Using the Logical Framework Approach. Johannesburg: Umhlaba Development Services.

Hennink, Monique, Inge Hutter, dan Ajay Bailey. 2011. Qualitative Research Methods, 1st Edition. California: SAGE Publications, Inc.

Independent Evaluation Office of UNDP. 2019. UNDP Evaluation Guidelines. New York: UNDP.

Muktiali, Mohammad. 2009. Penyusunan Instrumen Monitoring dan Evaluasi Manfaat Program Pembangunan di Kota Semarang. Riptek, Vol. 3, No. 2, Tahun 2009, Hal.: 11-20.

Patton, Carl V., David S. Sawicki, and Jennifer J. Clark. 2013. Basic Methods of Policy and Planning 3rd Edition. Boston: Pearson Education Inc.
The World Bank Operations Evaluation DepartmentEvaluation Capacity Development (OEDECD). 2004. Monitoring and Evaluation: Some Tools, Methods and Approaches. Washington, D.C.: The World Bank.

UNDP. 2009. Handbook on Planning, Monitoring and Evaluating for Development Results. New York: UNDP.

Naskah Peraturan dan Produk Kebijakan

DJPPR. 2019. Laporan Kinerja Penyerapan Pinjaman, Hibah dan Project Based Sukuk Triwulan I. Jakarta: DJPPR, Kementerian Keuangan.

. 2018. Laporan Kinerja Penyerapan Pinjaman, Hibah dan Project Based Sukuk Triwulan I. Jakarta: DJPPR, Kementerian Keuangan.

2018. Laporan Kinerja Penyerapan Pinjaman, Hibah dan Project Based Sukuk Triwulan II. Jakarta: DJPPR, Kementerian Keuangan.

2018. Laporan Kinerja Penyerapan Pinjaman, Hibah dan Project Based Sukuk Triwulan III. Jakarta: DJPPR, Kementerian Keuangan.

. 2018. Laporan Kinerja Penyerapan Pinjaman, Hibah dan Project Based Sukuk Triwulan IV. Jakarta: DJPPR, Kementerian Keuangan.

Kementerian Keuangan. 2011. PMK Nomor 224 Tahun 2011 tentang Tatacara Pemantauan dan Evaluasi atas Pinjaman dan Hibah kepada Pemerintah. Jakarta: Kementerian Keuangan.

Republik Indonesia. 2011. PP 10 Tahun 2011 tentang Tatacara Pengadaan Pinjaman Luar Negeri dan Penerimaan Hibah. Jakarta: Republik Indonesia.

2008. PP 54 Tahun 2008 tentang Tatacara Pengadaan dan Penerusan Pinjaman Dalam Negeri oleh Pemerintah. Jakarta: Republik Indonesia. 
DAFTAR PINJAMAN AKTIF PER 30 JUNI 2019

\begin{tabular}{|c|c|c|c|c|c|c|c|c|c|c|c|c|c|c|}
\hline No & $\begin{array}{l}\text { REGISTER } \\
\text { NO }\end{array}$ & $\begin{array}{l}\text { PEMBERI } \\
\text { PINJAMAN }\end{array}$ & NAMA PROYEK & $\begin{array}{l}\text { TANGGAL } \\
\text { LOAN }\end{array}$ & $\begin{array}{l}\text { BATAS } \\
\text { PENARIKAN } \\
\text { TERAKHIR }\end{array}$ & $\begin{array}{l}\text { MATA } \\
\text { UANG }\end{array}$ & NILAI PINJAMAN & $\begin{array}{l}\text { PINJAMAN YANG } \\
\text { TELAH DITARIK }\end{array}$ & $\begin{array}{l}\text { SISA PINJAMAN } \\
\text { YANG BELUM } \\
\text { DITARIK }\end{array}$ & $\begin{array}{l}\text { K/L PELAKSANA } \\
\text { PROYEK }\end{array}$ & ETR & DR & PV & KET. PV \\
\hline 1 & 21500201 & JICA & $\begin{array}{l}\text { RAILWAY ELECTRIFICATION AND } \\
\text { DOUBLE-DOUBLE TRACKING OF JAVA } \\
\text { MAIN LINE PROJECT (I) }\end{array}$ & 13-Dec-01 & 11-Sep-19 & JPY & $41.034 .000 .000,00$ & 19.673.638.761,00 & $21.360 .361 .239,00$ & KEMENHUB & 0,99 & 0,48 & 0,49 & $\begin{array}{l}\text { Behind } \\
\text { Schedule }\end{array}$ \\
\hline 2 & 21569501 & JICA & $\begin{array}{l}\text { ASAHAN NO.3 HYDROELECTRIC } \\
\text { POWER PLANT CONSTRUCTION } \\
\text { PROJECT }\end{array}$ & 29-Mar-06 & 31-Dec-22 & JPY & $27.642 .000 .000,00$ & $4.623 .742 .093,00$ & 23.018.257.907,00 & PT. PLN (PERSERO) & 0,76 & 0,17 & 0,22 & At Risk \\
\hline 3 & 21584001 & JICA & $\begin{array}{l}\text { HASANUDDIN UNIVERSITY } \\
\text { ENGINEERING FACULTY } \\
\text { DEVELOPMENT PROJECT } \\
\end{array}$ & 29-Mar-07 & 26-Jul-19 & JPY & $7.801 .000 .000,00$ & $7.547 .045 .684,00$ & 253.954.316,00 & KEMENRISTEKDIKTI & 0,99 & 0,97 & 0,97 & $\begin{array}{l}\text { Behind } \\
\text { Schedule }\end{array}$ \\
\hline 4 & 21581901 & JICA & $\begin{array}{l}\text { PEUSANGAN HYDROELECTRIC POWER } \\
\text { PLANT CONSTRUCTION PROJECT }\end{array}$ & 29-Mar-07 & 29-Jan-21 & JPY & $26.016 .000 .000,00$ & $21.619 .052 .186,00$ & 4.396.947.814,00 & PT. PLN (PERSERO) & 0,87 & 0,83 & 0,96 & $\begin{array}{l}\text { Behind } \\
\text { Schedule }\end{array}$ \\
\hline 5 & 10780201 & IFAD & VILLAGE DEVELOPMENT PROGRAMME & 18-Nov-08 & 30-Jun-19 & SDR & $42.033 .300,00$ & $41.973 .169,86$ & $60.130,14$ & KEMENDESA & 1,00 & 1,00 & 1,00 & $\begin{array}{l}\text { On and } \\
\text { ahead } \\
\text { Schedule }\end{array}$ \\
\hline 6 & 21619501 & JICA & $\begin{array}{l}\text { CONSTRUCTION OF JAKARTA MASS } \\
\text { RAPID TRANSIT PROJECT (I) }\end{array}$ & 31-Mar-09 & 28-Jul-19 & JPY & $48.150 .000 .000,00$ & 48.131.267.599,00 & $18.732 .401,00$ & KEMENHUB & 0,99 & 1,00 & 1,01 & $\begin{array}{l}\text { On and } \\
\text { ahead } \\
\text { Schedule }\end{array}$ \\
\hline 7 & 21620201 & JICA & $\begin{array}{l}\text { ENGINEERING SERVICES FOR JAVA- } \\
\text { SUMATERA INTERCONNECTION } \\
\text { TRANSMISSION LINE PROJECT } \\
\end{array}$ & 31-Mar-09 & 30-Sep-19 & JPY & $3.886 .000 .000,00$ & 1.572.911.089,00 & 2.313.088.911,00 & PT. PLN (PERSERO) & 0,97 & 0,40 & 0,42 & $\begin{array}{l}\text { Behind } \\
\text { Schedule }\end{array}$ \\
\hline 8 & 10801901 & IDB & $\begin{array}{l}\text { THE DEVELOPMENT OF BELAWAN } \\
\text { PORT PROJECT PHASE I }\end{array}$ & 14-Dec-09 & 05-May-19 & USD & $87.550 .000,00$ & $51.484 .814,00$ & $36.065 .186,00$ & KEMENHUB & 1,02 & 0,59 & 0,58 & $\begin{array}{l}\text { Behind } \\
\text { Schedule }\end{array}$ \\
\hline 9 & 21634001 & JICA & $\begin{array}{l}\text { JAVA-SUMATRA INTERCONNECTION } \\
\text { TRANSMISSION LINE PROJECT (1) }\end{array}$ & 30-Apr-10 & 30-Apr-22 & $J P Y$ & $36.994 .000 .000,00$ & $1.706 .628 .617,00$ & $35.287 .371 .383,00$ & PT. PLN (PERSERO) & 0,69 & 0,05 & 0,07 & At Risk \\
\hline 10 & 10811901 & ADB-OF & $\begin{array}{l}\text { METROPOLITAN SANITATION } \\
\text { MANAGEMENT AND HEALTH PROJECT }\end{array}$ & 21-Sep-10 & 31-Dec-20 & USD & $35.000 .000,00$ & 23.106.661,52 & $11.893 .338,48$ & KEMEN PU \& PERA & 0,85 & 0,66 & 0,78 & $\begin{array}{l}\text { Behind } \\
\text { Schedule }\end{array}$ \\
\hline 11 & 10814001 & IBRD & $\begin{array}{l}\text { POWER TRANSMISSION } \\
\text { DEVELOPMENT PROJECT }\end{array}$ & 18-Nov-10 & 31-Oct-19 & USD & $205.000 .000,00$ & $170.039 .510,27$ & $34.960 .489,73$ & PT. PLN (PERSERO) & 0,96 & 0,83 & 0,86 & $\begin{array}{l}\text { Behind } \\
\text { Schedule }\end{array}$ \\
\hline 12 & 21646401 & JICA & $\begin{array}{l}\text { LUMUT BALAI GEOTHERMAL POWER } \\
\text { PLANT PROJECT (IP-557) }\end{array}$ & 29-Mar-11 & 25-Oct-19 & JPY & $26.966 .000 .000,00$ & $10.228 .400 .109,00$ & $16.737 .599 .891,00$ & PT. PERTAMINA & 0,96 & 0,38 & 0,40 & $\begin{array}{l}\text { Behind } \\
\text { Schedule }\end{array}$ \\
\hline 13 & 10820201 & IDB & $\begin{array}{l}\text { THE QUALITY IMPROVEMENT OF } \\
\text { PADJADJARAN UNIVERSITY }\end{array}$ & 24-Apr-11 & 07-Jan-19 & USD & $26.998 .000,00$ & $26.974 .899,00$ & $23.101,00$ & KEMENRISTEKDIKTI & 1,06 & 1,00 & 0,94 & $\begin{array}{l}\text { Behind } \\
\text { Schedule }\end{array}$ \\
\hline 14 & 10823301 & IFAD & $\begin{array}{l}\text { SMALLHOLDER LIVELIHOOD } \\
\text { DEVELOPMENT PROJECT IN EASTERN } \\
\text { INDONESIA (SOLID) } \\
\end{array}$ & 05-Jul-11 & 31-Jul-19 & SDR & $30.300 .000,00$ & $29.402 .751,94$ & $897.248,06$ & KEMENTAN & 0,99 & 0,97 & 0,98 & $\begin{array}{l}\text { Behind } \\
\text { Schedule }\end{array}$ \\
\hline 15 & 10841901 & IBRD & $\begin{array}{l}\text { PUMPED STORAGE TECHNICAL } \\
\text { ASSISTANCE PROJECT (8057-ID) }\end{array}$ & 29-Nov-11 & 30-Nov-20 & USD & $44.000 .000,00$ & $35.751 .671,81$ & $8.248 .328,19$ & PT. PLN (PERSERO) & 0,83 & 0,81 & 0,97 & $\begin{array}{l}\text { Behind } \\
\text { Schedule }\end{array}$ \\
\hline 16 & 10842601 & IBRD & $\begin{array}{l}\text { WESTERN INDONESIA NATIONAL } \\
\text { ROADS }\end{array}$ & 14-Dec-11 & 28-Feb-21 & USD & $250.000 .000,00$ & 194.065.173,21 & $55.934 .826,79$ & KEMEN PU \& PERA & 0,81 & 0,78 & 0,95 & $\begin{array}{l}\text { Behind } \\
\text { Schedule }\end{array}$ \\
\hline
\end{tabular}




\begin{tabular}{|c|c|c|c|c|c|c|c|c|c|c|c|c|c|c|}
\hline No & $\begin{array}{l}\text { REGISTER } \\
\text { NO }\end{array}$ & $\begin{array}{l}\text { PEMBERI } \\
\text { PINJAMAN }\end{array}$ & NAMA PROYEK & $\begin{array}{l}\text { TANGGAL } \\
\text { LOAN }\end{array}$ & $\begin{array}{l}\text { BATAS } \\
\text { PENARIKAN } \\
\text { TERAKHIR }\end{array}$ & $\begin{array}{l}\text { MATA } \\
\text { UANG }\end{array}$ & NILAI PINJAMAN & $\begin{array}{l}\text { PINJAMAN YANG } \\
\text { TELAH DITARIK }\end{array}$ & $\begin{array}{l}\text { SISA PINJAMAN } \\
\text { YANG BELUM } \\
\text { DITARIK }\end{array}$ & $\begin{array}{l}\text { K/L PELAKSANA } \\
\text { PROYEK }\end{array}$ & ETR & DR & PV & KET. PV \\
\hline 17 & 21654001 & $\begin{array}{l}\text { EXIM BANK } \\
\text { KOREA }\end{array}$ & $\begin{array}{l}\text { CONSTRUCTION OF KARIAN } \\
\text { MULTIPURPOSE DAM PROJECT }\end{array}$ & 22-Dec-11 & 14-Jun-22 & KRW & $\begin{array}{r}109.426 .000 .000,0 \\
0\end{array}$ & $55.379 .143 .740,00$ & $54.046 .856 .260,00$ & KEMEN PU \& PERA & 0,71 & 0,51 & 0,71 & $\begin{array}{l}\text { Behind } \\
\text { Schedule }\end{array}$ \\
\hline 18 & 10845701 & IBRD & $\begin{array}{l}\text { Jakarta Urgent Flood Mitigation } \\
\text { Project/Jakarta Emergency Dredging } \\
\text { Initiative }\end{array}$ & 17-Feb-12 & 28-Feb-19 & USD & $139.640 .000,00$ & $94.314 .223,70$ & $45.325 .776,30$ & KEMEN PU \& PERA & 1,05 & 0,68 & 0,64 & $\begin{array}{l}\text { Behind } \\
\text { Schedule }\end{array}$ \\
\hline 19 & 10848801 & IDB & $\begin{array}{l}\text { REGIONAL ROADS DEVELOPMENT } \\
\text { PROJECT }\end{array}$ & 17-Apr-12 & 10-Jun-19 & USD & $65.000 .000,00$ & $36.242 .849,44$ & $28.757 .150,56$ & KEMEN PU \& PERA & 1,01 & 0,56 & 0,55 & $\begin{array}{l}\text { Behind } \\
\text { Schedule }\end{array}$ \\
\hline 20 & 40230201 & $\begin{array}{l}\text { PT. BNI- } \\
\text { SINGAPORE }\end{array}$ & $\begin{array}{l}\text { PROCUREMENT OF RETROFIT AND } \\
\text { UPGRADE C-13OB MODEL ( } 5 \text { AIR } \\
\text { CRAFTS) }\end{array}$ & 17-Jul-12 & 31-Aug-19 & USD & $54.162 .498,25$ & $47.446 .879,53$ & $6.715 .618,72$ & KEMHAN & 0,98 & 0,88 & 0,90 & $\begin{array}{l}\text { Behind } \\
\text { Schedule }\end{array}$ \\
\hline 21 & 10858801 & ADB-OF & $\begin{array}{l}\text { POLYTECHNIC EDUCATION } \\
\text { DEVELOPMENT PROJECT }\end{array}$ & 21-Nov-12 & 31-Dec-19 & USD & $75.000 .000,00$ & $72.155 .195,05$ & $2.844 .804,95$ & KEMENRISTEKDIKTI & 0,93 & 0,96 & 1,04 & $\begin{array}{l}\text { On and } \\
\text { ahead } \\
\text { Schedule }\end{array}$ \\
\hline 22 & 10859501 & ADB-OF & $\begin{array}{l}\text { STATE ACCOUNTABILITY } \\
\text { REVITALIZATION PROJECT }\end{array}$ & 26-Nov-12 & 31-Mar-20 & USD & $57.750 .000,00$ & $56.840 .791,40$ & $909.208,60$ & BPKP & 0,89 & 0,98 & 1,10 & $\begin{array}{l}\text { On and } \\
\text { ahead } \\
\text { Schedule }\end{array}$ \\
\hline 23 & 10862601 & IBRD & Village Innovation Program & 22-Jan-13 & 31-Dec-19 & USD & $650.000 .000,00$ & $596.344 .478,77$ & $53.655 .521,23$ & KEMENDESA & 0,93 & 0,92 & 0,99 & $\begin{array}{l}\text { Behind } \\
\text { Schedule }\end{array}$ \\
\hline 24 & 10863301 & IDB & $\begin{array}{l}\text { THE SUPPORT TO DEVELOPMENT OF } \\
\text { ISLAMIC HIGHER EDUCATION PROJECT }\end{array}$ & 16-Feb-13 & 11-Mar-20 & USD & $123.750 .000,00$ & $14.237 .865,65$ & $109.512 .134,35$ & KEMENAG & 0,90 & 0,12 & 0,13 & At Risk \\
\hline 25 & 21668801 & JICA & $\begin{array}{l}\text { UPPER CITARUM BASIN FLOOD } \\
\text { MANAGEMENT SECTOR LOAN }\end{array}$ & 28-Mar-13 & 25-Jul-20 & JPY & $3.311 .000 .000,00$ & 1.078.244.478,48 & 2.232.755.521,53 & KEMEN PU \& PERA & 0,85 & 0,33 & 0,38 & $\begin{array}{l}\text { Behind } \\
\text { Schedule }\end{array}$ \\
\hline 26 & 21669501 & JICA & $\begin{array}{l}\text { GEOTHERMAL DEVELOPMENT } \\
\text { ACCELERATION PROGRAM (TULEHU } \\
\text { GEOTHERMAL POWER PLANT PROJECT } \\
(\mathrm{E} / \mathrm{S}) \text { ) }\end{array}$ & 28-Mar-13 & 23-Oct-22 & JPY & $5.104 .000 .000,00$ & $3.354 .338 .164,00$ & $1.749 .661 .836,00$ & PT. PLN (PERSERO) & 0,63 & 0,66 & 1,04 & $\begin{array}{l}\text { On and } \\
\text { ahead } \\
\text { Schedule }\end{array}$ \\
\hline 27 & 21670201 & JICA & $\begin{array}{l}\text { INDRAMAYU COAL FIRED POWER } \\
\text { PLANT PROJECT (E/S) }\end{array}$ & 28-Mar-13 & 23-Oct-22 & JPY & $1.727 .000 .000,00$ & $615.537 .314,00$ & $1.111 .462 .686,00$ & PT. PLN (PERSERO) & 0,63 & 0,36 & 0,56 & $\begin{array}{l}\text { Behind } \\
\text { Schedule }\end{array}$ \\
\hline 28 & 10864001 & IBRD & $\begin{array}{l}\text { RESEARCH AND INNOVATION IN } \\
\text { SCIENCE AND TECHNOLOGY PROJECT }\end{array}$ & 12-Apr-13 & 31-Dec-20 & USD & $80.000 .000,00$ & $60.951 .344,88$ & $19.048 .655,12$ & KEMENRISTEKDIKTI & 0,80 & 0,76 & 0,95 & $\begin{array}{l}\text { Behind } \\
\text { Schedule }\end{array}$ \\
\hline 29 & 21667101 & $\mathrm{KfW}$ & $\begin{array}{l}\text { EMISSION REDUCTION IN CITIES SOLID } \\
\text { WASTE MANAGEMENT }\end{array}$ & 02-May-13 & 31-Dec-19 & EUR & $75.000 .000,00$ & 16.147.922,42 & $58.852 .077,58$ & KEMEN PU \& PERA & 0,91 & 0,22 & 0,24 & At Risk \\
\hline 30 & 10866401 & IDB & $\begin{array}{l}\text { SUPPORT TO QUALITY } \\
\text { IMPROVEMENTS PROJECT IN } \\
\text { INDONESIA (REVITALLZATION OF } \\
\text { VOCATIONAL TRAINING CENTERS } \\
\text { (VTCS)) }\end{array}$ & 17-Jul-13 & 30-Jun-19 & ACU & $1.600 .000,00$ & $1.325 .025,74$ & $274.974,26$ & KEMENAKER & 1,00 & 0,83 & 0,83 & $\begin{array}{l}\text { Behind } \\
\text { Schedule }\end{array}$ \\
\hline 31 & 10868801 & IBRD & $\begin{array}{l}\text { SECOND POWER TRANSMISSION } \\
\text { DEVELOPMENT PROJECT/SCATTERED } \\
\text { TRANSMISSION LINES AND } \\
\text { SUBSTATIONS IN INDONESIA PHASE II }\end{array}$ & 28-Aug-13 & 31-Dec-19 & USD & $137.600 .000,00$ & $78.280 .936,93$ & $59.319 .063,07$ & PT. PLN (PERSERO) & 0,91 & 0,57 & 0,62 & $\begin{array}{l}\text { Behind } \\
\text { Schedule }\end{array}$ \\
\hline 32 & 10869501 & ADB-OF & $\begin{array}{l}\text { STRENGTHENING WEST KALIMANTAN } \\
\text { POWER GRID PROJECT }\end{array}$ & 17-Oct-13 & 30-Nov-19 & USD & $49.500 .000,00$ & $40.019 .547,00$ & $9.480 .453,00$ & PT. PLN (PERSERO) & 0,93 & 0,81 & 0,87 & $\begin{array}{l}\text { Behind } \\
\text { Schedule }\end{array}$ \\
\hline
\end{tabular}




\begin{tabular}{|c|c|c|c|c|c|c|c|c|c|c|c|c|c|c|}
\hline No & $\begin{array}{l}\text { REGISTER } \\
\text { NO }\end{array}$ & $\begin{array}{l}\text { PEMBERI } \\
\text { PINJAMAN }\end{array}$ & NAMA PROYEK & $\begin{array}{l}\text { TANGGAL } \\
\text { LOAN }\end{array}$ & $\begin{array}{l}\text { BATAS } \\
\text { PENARIKAN } \\
\text { TERAKHIR }\end{array}$ & $\begin{array}{l}\text { MATA } \\
\text { UANG }\end{array}$ & NILAI PINJAMAN & $\begin{array}{l}\text { PINJAMAN YANG } \\
\text { TELAH DITARIK }\end{array}$ & $\begin{array}{l}\text { SISA PINJAMAN } \\
\text { YANG BELUM } \\
\text { DITARIK }\end{array}$ & $\begin{array}{l}\text { K/L PELAKSANA } \\
\text { PROYEK }\end{array}$ & ETR & DR & PV & KET. PV \\
\hline 33 & 10877101 & ADB-OF & $\begin{array}{l}\text { JAVA BALI } 500 \text { KV POWER } \\
\text { TRANSMISSION CROSSING PROJECT }\end{array}$ & 30-Dec-13 & 30-Sep-19 & USD & $18.751 .192,34$ & $15.788 .281,24$ & $2.962 .911,10$ & PT. PLN (PERSERO) & 0,95 & 0,84 & 0,89 & $\begin{array}{l}\text { Behind } \\
\text { Schedule }\end{array}$ \\
\hline 34 & 10878801 & ADB-OF & $\begin{array}{l}\text { JAVA BALI } 500 \text { KV POWER } \\
\text { TRANSMISSION CROSSING PROJECT }\end{array}$ & 30-Dec-13 & 30-Sep-19 & USD & $2.083 .411,09$ & $1.747 .494,23$ & $335.916,86$ & PT. PLN (PERSERO) & 0,95 & 0,84 & 0,88 & $\begin{array}{l}\text { Behind } \\
\text { Schedule }\end{array}$ \\
\hline 35 & 10879501 & IDB & $\begin{array}{l}\text { THE SUPPORT TO THE DEVELOPMENT } \\
\text { OF HIGHER EDUCATION PROJECT }\end{array}$ & 02-Jan-14 & 27-Oct-19 & USD & $174.010 .000,00$ & $126.332 .956,75$ & $47.677 .043,25$ & KEMENRISTEKDIKTI & 0,94 & 0,73 & 0,77 & $\begin{array}{l}\text { Behind } \\
\text { Schedule }\end{array}$ \\
\hline 36 & 10880201 & IDB & $\begin{array}{l}\text { COMMUNITY BASED SANITATION } \\
\text { PROJECT IN INDONESIA/ COMMUNITY } \\
\text { BASED SANITATION } \\
\text { PROGRAM/SANIMAS } \\
\end{array}$ & 19-Feb-14 & 12-Jun-20 & USD & $100.000 .000,00$ & $70.710 .966,00$ & $29.289 .034,00$ & KEMEN PU \& PERA & 0,84 & 0,71 & 0,85 & $\begin{array}{l}\text { Behind } \\
\text { Schedule }\end{array}$ \\
\hline 37 & 21678801 & JICA & $\begin{array}{l}\text { RAILWAY DOUBLE TRACKING ON JAVA } \\
\text { SOUTH LINE PROJECT (IV) (KROYA- } \\
\text { KUTOARJO PHASE II) } \\
\end{array}$ & 24-Feb-14 & 23-Jun-21 & $J P Y$ & $16.875 .000 .000,00$ & 0,00 & $16.875 .000 .000,00$ & KEMENHUB & 0,72 & 0,00 & 0,00 & At Risk \\
\hline 38 & 21679501 & JICA & $\begin{array}{l}\text { JABODETABEK RAILWAY CAPACITY } \\
\text { ENHANCEMENT PHASE I }\end{array}$ & 24-Feb-14 & 23-Jun-21 & $J P Y$ & $16.322 .000 .000,00$ & 0,00 & $16.322 .000 .000,00$ & KEMENHUB & 0,72 & 0,00 & 0,00 & At Risk \\
\hline 39 & 21683301 & JICA & $\begin{array}{l}\text { METROPOLITAN SANITATION } \\
\text { MANAGEMENT INVESTMENT } \\
\text { PROGRAM: ENGINEERING SERVICES } \\
\text { FOR SEWERAGE SYSTEM } \\
\text { DEVELOPMENT IN DKI JAKARTA }\end{array}$ & 24-Feb-14 & 23-Jun-21 & $J P Y$ & $1.968 .000 .000,00$ & $741.635 .244,00$ & $1.226 .364 .756,00$ & KEMEN PU \& PERA & 0,72 & 0,38 & 0,53 & $\begin{array}{l}\text { Behind } \\
\text { Schedule }\end{array}$ \\
\hline 40 & 21682601 & JICA & $\begin{array}{l}\text { URGENT DISASTER REDUCTION } \\
\text { PROJECT FOR MOUNT MERAPI AND } \\
\text { LOWER PROGO RIVER AREA II }\end{array}$ & 24-Feb-14 & 23-Jun-21 & $J P Y$ & $5.111 .000 .000,00$ & $4.120 .330 .108,00$ & $990.669 .892,00$ & KEMEN PU \& PERA & 0,72 & 0,81 & 1,12 & $\begin{array}{l}\text { On and } \\
\text { ahead } \\
\text { Schedule }\end{array}$ \\
\hline 41 & 21684001 & JICA & $\begin{array}{l}\text { COUNTERMEASURE FOR SEDIMENT IN } \\
\text { WONOGIRI MULTIPURPOSE DAM } \\
\text { RESERVOIR (II) }\end{array}$ & 24-Feb-14 & 23-Jun-21 & JPY & $4.954 .000 .000,00$ & $1.915 .002 .845,00$ & 3.038.997.155,00 & KEMEN PU \& PERA & 0,72 & 0,39 & 0,54 & $\begin{array}{l}\text { Behind } \\
\text { Schedule }\end{array}$ \\
\hline 42 & 21680201 & JICA & $\begin{array}{l}\text { PROFESSIONAL HUMAN RESOURCE } \\
\text { DEVELOPMENT (IV) }\end{array}$ & 24-Feb-14 & 23-Jun-23 & $J P Y$ & $7.075 .000 .000,00$ & $4.057 .265 .269,00$ & $3.017 .734 .731,00$ & $\begin{array}{l}\text { MENEG } \\
\text { PPN/BAPPENAS }\end{array}$ & 0,56 & 0,57 & 1,03 & $\begin{array}{l}\text { On and } \\
\text { ahead } \\
\text { Schedule }\end{array}$ \\
\hline 43 & 21685701 & SFD & $\begin{array}{l}\text { DEVELOPMENT OF EDUCATION IN } \\
\text { SEVEN UNIVERSITIES }\end{array}$ & 12-Mar-14 & 31-Dec-19 & SAR & $131.250 .000,00$ & $83.434 .494,76$ & $47.815 .505,24$ & KEMENRISTEKDIKTI & 0,90 & 0,64 & 0,70 & $\begin{array}{l}\text { Behind } \\
\text { Schedule }\end{array}$ \\
\hline 44 & 10881901 & IBRD & $\begin{array}{l}\text { CORAL REEF REHABILITATION AND } \\
\text { MANAGEMENT PROGRAM - CORAL } \\
\text { TRIANGLE INITIATIVE (COREMAP-CTI) } \\
\text { PROJECT }\end{array}$ & 17-Mar-14 & 30-Jun-22 & USD & $47.380 .000,00$ & $25.000 .000,00$ & $22.380 .000,00$ & LIPI & 0,63 & 0,53 & 0,84 & $\begin{array}{l}\text { Behind } \\
\text { Schedule }\end{array}$ \\
\hline 45 & 21687101 & $\begin{array}{l}\text { EXIM BANK } \\
\text { KOREA }\end{array}$ & $\begin{array}{l}\text { DEVELOPMENT OF SEWERAGE } \\
\text { SYSTEM IN BATAM ISLAND PROJECT }\end{array}$ & 21-Mar-14 & 30-Jun-21 & $\mathrm{KRW}$ & $57.397 .000 .000,00$ & $22.853 .456 .940,00$ & $34.543 .543 .060,00$ & BP BATAM & 0,69 & 0,40 & 0,58 & $\begin{array}{l}\text { Behind } \\
\text { Schedule }\end{array}$ \\
\hline 46 & 10882601 & ADB-OF & $\begin{array}{l}\text { NEIGHBORHOOD UPGRADING AND } \\
\text { SHELTER PROJECT-PHASE } 2\end{array}$ & 23-Apr-14 & 31-Dec-19 & USD & $74.400 .000,00$ & $72.320 .204,52$ & $2.079 .795,48$ & KEMEN PU \& PERA & 0,91 & 0,97 & 1,07 & $\begin{array}{l}\text { On and } \\
\text { ahead } \\
\text { Schedule }\end{array}$ \\
\hline 47 & 10884001 & ADB-OF & $\begin{array}{l}\text { METROPOLITAN SANITATION } \\
\text { MANAGEMENT INVESTMENT PROJECT }\end{array}$ & 13-May-14 & 31-Dec-20 & USD & $40.000 .000,00$ & 0,00 & $40.000 .000,00$ & KEMEN PU \& PERA & 0,77 & 0,00 & 0,00 & At Risk \\
\hline 48 & 10883301 & ADB-OF & $\begin{array}{l}\text { METROPOLITAN SANITATION } \\
\text { MANAGEMENT INVESTMENT PROJECT }\end{array}$ & 13-May-14 & 31-Dec-20 & USD & $80.000 .000,00$ & $3.436 .439,86$ & $76.563 .560,14$ & KEMEN PU \& PERA & 0,77 & 0,04 & 0,06 & At Risk \\
\hline
\end{tabular}




\begin{tabular}{|c|c|c|c|c|c|c|c|c|c|c|c|c|c|c|}
\hline No & $\begin{array}{l}\text { REGISTER } \\
\text { NO }\end{array}$ & $\begin{array}{l}\text { PEMBERI } \\
\text { PINJAMAN }\end{array}$ & NAMA PROYEK & $\begin{array}{l}\text { TANGGAL } \\
\text { LOAN }\end{array}$ & $\begin{array}{l}\text { BATAS } \\
\text { PENARIKAN } \\
\text { TERAKHIR }\end{array}$ & $\begin{array}{l}\text { MATA } \\
\text { UANG }\end{array}$ & NILAI PINJAMAN & $\begin{array}{l}\text { PINJAMAN YANG } \\
\text { TELAH DITARIK }\end{array}$ & $\begin{array}{l}\text { SISA PINJAMAN } \\
\text { YANG BELUM } \\
\text { DITARIK }\end{array}$ & $\begin{array}{l}\text { K/L PELAKSANA } \\
\text { PROYEK }\end{array}$ & ETR & DR & PV & KET. PV \\
\hline 49 & 168FGN47 & $\begin{array}{l}\text { CACIB } \\
\text { LONDON } \\
\text { BRANCH } \\
\end{array}$ & $\begin{array}{l}\text { PENGADAAN SHORT RANGE AIR } \\
\text { DEFENCE (STARSTREAK) }\end{array}$ & 12-Nov-14 & 30-Jun-19 & USD & $119.000 .000,00$ & $103.679 .775,82$ & $15.320 .224,18$ & KEMHAN & 1,00 & 0,87 & 0,87 & $\begin{array}{l}\text { Behind } \\
\text { Schedule }\end{array}$ \\
\hline 50 & $1 \mathrm{KVX} 1 \mathrm{BJJ}$ & $\mathrm{KfW}$ & $\begin{array}{l}\text { SCATTERED TRANSMISSIONS AND } \\
\text { SUBSTATIONS PROJECT PACKAGE } 3\end{array}$ & 05-Dec-14 & 30-Nov-19 & EUR & 16.299.910,19 & $12.859 .490,30$ & $3.440 .419,89$ & PT. PLN (PERSERO) & 0,84 & 0,79 & 0,94 & $\begin{array}{l}\text { Behind } \\
\text { Schedule }\end{array}$ \\
\hline 51 & 1BP6X78W & $\begin{array}{l}\text { EXIM BANK } \\
\text { OF CHINA }\end{array}$ & $\begin{array}{l}\text { PREFERENTIAL BUYER CREDIT LOAN } \\
\text { AGREEMENT ON TAKALAR COAL FIRED } \\
\text { STEAM POWER PLANT PROJECT } \\
\text { (2X100MW) }\end{array}$ & 22-Dec-14 & 29-Apr-20 & USD & $240.983 .647,00$ & $229.882 .318,71$ & $11.101 .328,29$ & PT. PLN (PERSERO) & 0,83 & 0,95 & 1,14 & $\begin{array}{l}\text { On and } \\
\text { ahead } \\
\text { Schedule }\end{array}$ \\
\hline 52 & 1DRENEXS & $\begin{array}{l}\text { EXIM BANK } \\
\text { OF CHINA }\end{array}$ & $\begin{array}{l}\text { PREFERENTIAL BUYER CREDIT LOAN } \\
\text { AGREEMENT ON PANGKALAN SUSU } \\
\text { COAL FIRED STEAM POWER PLANT } \\
\text { PROJECT UNIT } 3 \& 4 \text { (2X100MW) }\end{array}$ & 22-Dec-14 & 03-Jun-20 & USD & $373.009 .532,12$ & $234.516 .285,50$ & $138.493 .246,62$ & PT. PLN (PERSERO) & 0,81 & 0,63 & 0,77 & $\begin{array}{l}\text { Behind } \\
\text { Schedule }\end{array}$ \\
\hline 53 & 18TESRZ6 & $\begin{array}{l}\text { SOCIETE } \\
\text { GENERALE }\end{array}$ & $\begin{array}{l}\text { MODIFIKASI TEST BENCH EXOCET DI } \\
\text { ARSENAL }\end{array}$ & 10-Sep-15 & 10-Jul-19 & EUR & $6.433 .650,00$ & $5.808 .460,00$ & $625.190,00$ & KEMHAN & 0,99 & 0,90 & 0,91 & $\begin{array}{l}\text { Behind } \\
\text { Schedule }\end{array}$ \\
\hline 54 & 1BSPSXGQ & $\begin{array}{l}\text { BRI- } \\
\text { CAYMAN } \\
\text { ISLAND } \\
\end{array}$ & $\begin{array}{l}11 \text { Helikopter Anti Kapal Selam (AKS) } \\
\text { dan Suku Cadang (BRI CAYMAN } \\
\text { ISLAND) }\end{array}$ & 25-Sep-15 & 25-Sep-19 & EUR & $21.650 .868,50$ & 14.157.186,13 & $7.493 .682,37$ & KEMHAN & 0,94 & 0,65 & 0,70 & $\begin{array}{l}\text { Behind } \\
\text { Schedule }\end{array}$ \\
\hline 55 & 1SYAFNR7 & $\begin{array}{l}\text { BNP } \\
\text { PARIBAS, } \\
\text { PARIS } \\
\end{array}$ & EXOCET MM-40 BLOCK3 + MISTRAL2 & 30-Sep-15 & 15-Nov-19 & EUR & $17.311 .440,00$ & $16.307 .580,00$ & $1.003 .860,00$ & KEMHAN & 0,91 & 0,94 & 1,04 & $\begin{array}{l}\text { On and } \\
\text { ahead } \\
\text { Schedule }\end{array}$ \\
\hline 56 & 1LZT4FLA & JICA & $\begin{array}{l}\text { ENGINEERING SERVICES FOR JAKARTA } \\
\text { MASS RAPID TRANSIT EAST-WEST LINE } \\
\text { PROJECT (PHASE I) }\end{array}$ & 04-Dec-15 & 31-Mar-22 & $J P Y$ & $1.919 .000 .000,00$ & 0,00 & $1.919 .000 .000,00$ & KEMENHUB & 0,54 & 0,00 & 0,00 & $\begin{array}{l}\text { Behind } \\
\text { Schedule }\end{array}$ \\
\hline 57 & 1815NP6A & JICA & $\begin{array}{l}\text { CONSTRUCTION OF JAKARTA MASS } \\
\text { RAPID TRANSIT PROJECT (II) } \\
\text { (CONSTRUCTION JAKARTA MASS } \\
\text { RAPID TRANSIT PHASE I STAGE 2) }\end{array}$ & 04-Dec-15 & 31-Mar-22 & $J P Y$ & $75.218 .000 .000,00$ & $50.420 .522 .631,00$ & 24.797.477.369,00 & KEMENHUB & 0,54 & 0,67 & 1,24 & $\begin{array}{l}\text { On and } \\
\text { ahead } \\
\text { Schedule }\end{array}$ \\
\hline 58 & 1PMU146A & JICA & $\begin{array}{l}\text { JAVA-SUMATRA INTERCONNECTION } \\
\text { TRANSMISSION LINE PROJECT (II) }\end{array}$ & 18-Dec-15 & 14-Apr-23 & JPY & $62.914 .000 .000,00$ & 0,00 & $62.914 .000 .000,00$ & PT. PLN (PERSERO) & $-0,08$ & 0,00 & 0,00 & $\begin{array}{l}\text { Behind } \\
\text { Schedule }\end{array}$ \\
\hline 59 & 16ER6MYA & JICA & $\begin{array}{l}\text { GEOTHERMAL DEVELOPMENT } \\
\text { ACCELERATION PROGRAM (HULULAIS } \\
\text { GEOTHERMAL POWER PLANT PROJECT } \\
(\text { E/S)) }\end{array}$ & 18-Dec-15 & 14-Oct-25 & JPY & $657.000 .000,00$ & $168.263 .846,00$ & $488.736 .154,00$ & PT. PLN (PERSERO) & 0,30 & 0,26 & 0,85 & $\begin{array}{l}\text { Behind } \\
\text { Schedule }\end{array}$ \\
\hline 60 & 1JJKXGXA & BBVAIT & $\begin{array}{l}\text { PROCUREMENT OF CALLIBER 4OMM } \\
\text { GUN TWIN BARREL }\end{array}$ & 22-Dec-15 & 30-Apr-19 & EUR & $9.732 .500,00$ & $5.725 .000,00$ & $4.007 .500,00$ & KEMHAN & 1,20 & 0,59 & 0,49 & $\begin{array}{l}\text { Behind } \\
\text { Schedule }\end{array}$ \\
\hline 61 & 1MZJG1EA & $\begin{array}{l}\text { EXIM BANK } \\
\text { OF CHINA }\end{array}$ & $\begin{array}{l}\text { PREFERENTIAL BUYER CREDIT LOAN } \\
\text { AGREEMENT ON TOLL ROAD } \\
\text { DEVELOPMENT OF SOLO KERTOSONO } \\
\text { PHASE I }\end{array}$ & 29-Dec-15 & 30-Sep-21 & USD & 198.772.234,89 & $169.597 .730,02$ & $29.174 .504,87$ & KEMEN PU \& PERA & 0,55 & 0,85 & 1,55 & $\begin{array}{l}\text { On and } \\
\text { ahead } \\
\text { Schedule }\end{array}$ \\
\hline 62 & 1VMMBHYA & $\begin{array}{l}\text { EXIM BANK } \\
\text { OF CHINA }\end{array}$ & $\begin{array}{l}\text { PREFERENTIAL BUYER CREDIT LOAN } \\
\text { AGREEMENT ON BALIKPAPAN } \\
\text { SAMARINDA TOLL ROAD } \\
\text { DEVELOPMENT SECTION } 5 \text { PROJECT }\end{array}$ & 29-Dec-15 & 30-Sep-21 & USD & $53.405 .755,75$ & $37.072 .647,25$ & $16.333 .108,50$ & KEMEN PU \& PERA & 0,55 & 0,69 & 1,26 & $\begin{array}{l}\text { On and } \\
\text { ahead } \\
\text { Schedule }\end{array}$ \\
\hline 63 & 1YJJ8PSA & IDB & $\begin{array}{l}\text { The Development of Four Higher } \\
\text { Education Institutions Project in the } \\
\text { Republic of Indonesia }\end{array}$ & 19-May-16 & 31-Dec-20 & USD & $13.870 .000,00$ & $5.618 .601,81$ & $8.251 .398,19$ & KEMENRISTEKDIKTI & 0,64 & 0,41 & 0,64 & $\begin{array}{l}\text { Behind } \\
\text { Schedule }\end{array}$ \\
\hline 64 & 1ZPWV5NA & IDB & $\begin{array}{l}\text { The Development of Four Higher } \\
\text { Education Institutions Project in the } \\
\text { Republic of Indonesia }\end{array}$ & 19-May-16 & 31-Dec-20 & USD & $162.630 .000,00$ & $26.328 .791,80$ & $136.301 .208,20$ & KEMENRISTEKDIKTI & 0,29 & 0,16 & 0,55 & $\begin{array}{l}\text { Behind } \\
\text { Schedule }\end{array}$ \\
\hline
\end{tabular}




\begin{tabular}{|c|c|c|c|c|c|c|c|c|c|c|c|c|c|c|}
\hline No & $\begin{array}{l}\text { REGISTER } \\
\text { NO }\end{array}$ & $\begin{array}{l}\text { PEMBERI } \\
\text { PINJAMAN }\end{array}$ & NAMA PROYEK & $\begin{array}{l}\text { TANGGAL } \\
\text { LOAN }\end{array}$ & $\begin{array}{l}\text { BATAS } \\
\text { PENARIKAN } \\
\text { TERAKHIR }\end{array}$ & $\begin{array}{l}\text { MATA } \\
\text { UANG }\end{array}$ & NILAI PINJAMAN & $\begin{array}{l}\text { PINJAMAN YANG } \\
\text { TELAH DITARIK }\end{array}$ & $\begin{array}{l}\text { SISA PINJAMAN } \\
\text { YANG BELUM } \\
\text { DITARIK }\end{array}$ & $\begin{array}{l}\text { K/L PELAKSANA } \\
\text { PROYEK }\end{array}$ & ETR & DR & PV & KET. PV \\
\hline 65 & 1VFX57JA & IDB & $\begin{array}{l}\text { The National Slum Upgrading Project } \\
\text { in the Republic of Indonesia }\end{array}$ & 19-May-16 & 04-May-21 & USD & $8.000 .000,00$ & $2.242 .203,32$ & $5.757 .796,68$ & KEMEN PU \& PERA & 0,59 & 0,28 & 0,48 & $\begin{array}{l}\text { Behind } \\
\text { Schedule }\end{array}$ \\
\hline 66 & 1ENYRFPA & IDB & $\begin{array}{l}\text { The National Slum Upgrading Project } \\
\text { in the Republic of Indonesia }\end{array}$ & 19-May-16 & 09-May-21 & USD & $311.760 .000,00$ & $117.539 .402,31$ & 194.220.597,69 & KEMEN PU \& PERA & 0,58 & 0,38 & 0,65 & $\begin{array}{l}\text { Behind } \\
\text { Schedule }\end{array}$ \\
\hline 67 & 1NT81PXA & IDB & $\begin{array}{l}\text { The National Slum Upgrading Project } \\
\text { in the Republic of Indonesia }\end{array}$ & 19-May-16 & 22-Nov-21 & USD & $10.000 .000,00$ & $689.552,00$ & $9.310 .448,00$ & KEMEN PU \& PERA & 0,52 & 0,07 & 0,13 & At Risk \\
\hline 68 & 15PR17RA & $\begin{array}{l}\text { EXIMBANK } \\
\text { HUNGARY }\end{array}$ & $\begin{array}{l}\text { IKK WATER SUPPLY PROGRAM AND } \\
\text { SMALL WATER TREATMENT PLANT } \\
\text { FOR WATER SCARCITY AREAS }\end{array}$ & 20-May-16 & 03-Aug-20 & USD & $36.443 .330,00$ & 28.666.919,89 & $7.776 .410,11$ & KEMEN PU \& PERA & 0,73 & 0,79 & 1,08 & $\begin{array}{l}\text { On and } \\
\text { ahead } \\
\text { Schedule }\end{array}$ \\
\hline 69 & 1RVNVDTA & $\begin{array}{l}\text { EXIM BANK } \\
\text { OF CHINA }\end{array}$ & $\begin{array}{l}\text { TOLL ROAD DEVELOPMENT OF } \\
\text { CILEUNYI SUMEDANG DAWUAN } \\
\text { PHASE II PROJECT }\end{array}$ & 13-Jun-16 & 30-Sep-21 & USD & $219.398 .580,06$ & $123.214 .655,12$ & 96.183.924,94 & KEMEN PU \& PERA & 0,55 & 0,56 & 1,02 & $\begin{array}{l}\text { On and } \\
\text { ahead } \\
\text { Schedule }\end{array}$ \\
\hline 70 & 1UG6AGFA & $\begin{array}{l}\text { EXIM BANK } \\
\text { OF CHINA }\end{array}$ & $\begin{array}{l}\text { TOLL ROAD DEVELOPMENT OF } \\
\text { MANADO BITUNG CSU-01 PROJECT }\end{array}$ & 13-Jun-16 & 30-Sep-21 & USD & $78.099 .963,04$ & $63.917 .585,53$ & $14.182 .377,51$ & KEMEN PU \& PERA & 0,55 & 0,82 & 1,49 & $\begin{array}{l}\text { On and } \\
\text { ahead } \\
\text { Schedule }\end{array}$ \\
\hline 71 & 1NPB3NNA & IBRD & $\begin{array}{l}\text { Second Additional Financing for Third } \\
\text { Water Supply and Sanitation for Low- } \\
\text { Income Communities/Community } \\
\text { Based Water Supply Project }\end{array}$ & 30-Jun-16 & 31-Dec-20 & USD & $300.000 .000,00$ & $136.250 .000,00$ & $163.750 .000,00$ & KEMEN PU \& PERA & 0,65 & 0,45 & 0,69 & $\begin{array}{l}\text { Behind } \\
\text { Schedule }\end{array}$ \\
\hline 72 & 1FWC3ABA & $\begin{array}{l}\text { EXIM BANK } \\
\text { KOREA }\end{array}$ & $\begin{array}{l}\text { ALIHANDAK EOD/MOLE } \\
\text { PROGRAMMER }\end{array}$ & 29-Jul-16 & 28-Aug-19 & USD & $5.930 .662,50$ & $2.870 .124,13$ & $3.060 .538,37$ & POLRI & 0,95 & 0,48 & 0,51 & $\begin{array}{l}\text { Behind } \\
\text { Schedule }\end{array}$ \\
\hline 73 & 13Y581LA & $\begin{array}{l}\text { EXIM BANK } \\
\text { OF CHINA }\end{array}$ & $\begin{array}{l}\text { PROCUREMENT OF TRACK MATERIAL } \\
\text { AND TURNOUT PHASE II PROJECT } \\
\text { (1500 KM'SP \& 500 UNITS) } \\
\end{array}$ & 18-Aug-16 & 24-Jan-20 & USD & $175.056 .055,00$ & 103.244.880,89 & 71.811.174,11 & KEMENHUB & 0,81 & 0,59 & 0,73 & $\begin{array}{l}\text { Behind } \\
\text { Schedule }\end{array}$ \\
\hline 74 & 18K6ECNA & IBRD & $\begin{array}{l}\text { NATIONAL SLUM UPGRADING } \\
\text { PROJECT }\end{array}$ & 22-Aug-16 & 31-Mar-22 & USD & $216.500 .000,00$ & $82.850 .000,00$ & $133.650 .000,00$ & KEMEN PU \& PERA & 0,50 & 0,38 & 0,77 & $\begin{array}{l}\text { Behind } \\
\text { Schedule }\end{array}$ \\
\hline 75 & 1PTDQQAA & AllB & $\begin{array}{l}\text { NATIONAL SLUM UPGRADING } \\
\text { PROJECT }\end{array}$ & 01-Sep-16 & 31-Mar-22 & USD & $216.500 .000,00$ & $82.850 .000,00$ & $133.650 .000,00$ & KEMEN PU \& PERA & 0,49 & 0,38 & 0,78 & $\begin{array}{l}\text { Behind } \\
\text { Schedule }\end{array}$ \\
\hline 76 & 1P4XZ2YA & $\begin{array}{l}\text { BNP } \\
\text { PARIBAS, } \\
\text { PARIS } \\
\end{array}$ & $\begin{array}{l}\text { PENGADAAN AIR WEAPON RANGE } \\
\text { (AWR) DAN AIR WEAPON SCORING } \\
\text { SYSTEM (AWSS) }\end{array}$ & 07-Sep-16 & 31-May-19 & USD & $4.152 .250,00$ & $2.687 .333,06$ & $1.464 .916,94$ & KEMHAN & 1,04 & 0,65 & 0,62 & $\begin{array}{l}\text { Behind } \\
\text { Schedule }\end{array}$ \\
\hline 77 & 1DK59PAA & $\begin{array}{l}\text { PT. BNI- } \\
\text { SINGAPORE }\end{array}$ & $\begin{array}{l}\text { PEMELIHARAAN DAN SUKU CADANG } \\
\text { KAPAL } 2009\end{array}$ & 13-Oct-16 & 01-Jul-19 & USD & $2.549 .299,44$ & $2.154 .238,04$ & $395.061,40$ & POLRI & 1,00 & 0,85 & 0,85 & $\begin{array}{l}\text { Behind } \\
\text { Schedule }\end{array}$ \\
\hline 78 & 14NJ3WNA & $\begin{array}{l}\text { BANK } \\
\text { MANDIRI } \\
\text { SIN }\end{array}$ & $\begin{array}{l}\text { PENGADAAN MUNISI KALIBER 105MM } \\
\text { HE }\end{array}$ & 21-Oct-16 & 20-Apr-19 & USD & $11.473 .645,10$ & $5.795 .362,40$ & $5.678 .282,70$ & KEMHAN & 1,62 & 0,51 & 0,31 & $\begin{array}{l}\text { Behind } \\
\text { Schedule }\end{array}$ \\
\hline 79 & $1 \mathrm{GGQ} 8 \mathrm{LAA}$ & $\begin{array}{l}\text { BANK } \\
\text { MANDIRI } \\
\text { SIN } \\
\end{array}$ & $\begin{array}{l}\text { PENGADAAN DAN PERBAIKAN SUCAD } \\
\text { TANK SCORPION }\end{array}$ & 21-Oct-16 & 19-Nov-19 & USD & $8.496 .523,48$ & $6.709 .773,22$ & $1.786 .750,26$ & KEMHAN & 0,82 & 0,79 & 0,96 & $\begin{array}{l}\text { Behind } \\
\text { Schedule }\end{array}$ \\
\hline 80 & $1 \mathrm{RUX78CA}$ & ADB-OF & $\begin{array}{l}\text { FLOOD MANAGEMENT IN SELECTED } \\
\text { RIVER BASINS SECTOR PROJECT }\end{array}$ & 02-Nov-16 & 30-Jun-23 & USD & $108.700 .000,00$ & $11.008 .456,29$ & $97.691 .543,71$ & KEMEN PU \& PERA & 0,39 & 0,10 & 0,26 & At Risk \\
\hline 81 & 1F1NDHGA & ADB-OF & $\begin{array}{l}\text { ACCELERATING INFRASTRUCTURE } \\
\text { DELIVERY THROUGH BETTER } \\
\text { ENGINEERING SERVICES PROJECT }\end{array}$ & 28-Nov-16 & 30-Jun-20 & USD & $148.200 .000,00$ & $3.586 .857,32$ & $144.613 .142,68$ & KEMEN PU \& PERA & 0,72 & 0,02 & 0,03 & At Risk \\
\hline
\end{tabular}




\begin{tabular}{|c|c|c|c|c|c|c|c|c|c|c|c|c|c|c|}
\hline No & $\begin{array}{l}\text { REGISTER } \\
\text { NO }\end{array}$ & $\begin{array}{l}\text { PEMBERI } \\
\text { PINJAMAN }\end{array}$ & NAMA PROYEK & $\begin{array}{l}\text { TANGGAL } \\
\text { LOAN }\end{array}$ & $\begin{array}{l}\text { BATAS } \\
\text { PENARIKAN } \\
\text { TERAKHIR }\end{array}$ & $\begin{array}{l}\text { MATA } \\
\text { UANG }\end{array}$ & NILAI PINJAMAN & $\begin{array}{l}\text { PINJAMAN YANG } \\
\text { TELAH DITARIK }\end{array}$ & $\begin{array}{l}\text { SISA PINJAMAN } \\
\text { YANG BELUM } \\
\text { DITARIK }\end{array}$ & $\begin{array}{l}\text { K/L PELAKSANA } \\
\text { PROYEK }\end{array}$ & ETR & DR & PV & KET. PV \\
\hline 82 & 1SR8AMNA & $\begin{array}{l}\text { UNICREDIT } \\
\text { BANK } \\
\text { AUSTR }\end{array}$ & $\begin{array}{l}\text { THE PROCUREMENT OF INTEGRATED } \\
\text { LOGISTIC SUPPORT CORVETTE SIGMA } \\
\text { CLASS }\end{array}$ & 06-Dec-16 & 06-Feb-20 & EUR & $19.141 .207,77$ & $4.777 .160,36$ & $14.364 .047,41$ & KEMHAN & 0,72 & 0,25 & 0,35 & $\begin{array}{l}\text { Behind } \\
\text { Schedule }\end{array}$ \\
\hline 83 & 1FESR85A & $\begin{array}{l}\text { ING BANK } \\
\text { AMSTERDA } \\
\text { M }\end{array}$ & $\begin{array}{l}\text { PROCUREMENT OF TWO (2) SHIPSET } \\
\text { FFBNW PKR VESSEL } 10514\end{array}$ & 14-Dec-16 & 14-Aug-20 & EUR & $166.961 .250,00$ & $58.927 .500,00$ & $108.033 .750,00$ & KEMHAN & 0,64 & 0,35 & 0,55 & $\begin{array}{l}\text { Behind } \\
\text { Schedule }\end{array}$ \\
\hline 84 & 1UENV33A & $\begin{array}{l}\text { BRI- } \\
\text { CAYMAN } \\
\text { ISLAND } \\
\end{array}$ & $\begin{array}{l}\text { SIMULATOR SUKHOI DAN } \\
\text { PENDUKUNGNYA }\end{array}$ & 25-Jan-17 & 25-Jan-20 & USD & $38.160 .750,00$ & $8.560 .000,00$ & $29.600 .750,00$ & KEMHAN & 0,81 & 0,22 & 0,28 & At Risk \\
\hline 85 & 1CWHNY7A & $\begin{array}{l}\text { BOTM } \\
\text { SINGAPORE }\end{array}$ & $\begin{array}{l}\text { PENGADAAN PERALATAN DISASTER } \\
\text { VICTIM IDENTIFICATION }\end{array}$ & 27-Jan-17 & 27-May-19 & USD & $5.939 .237,16$ & 0,00 & $5.939 .237,16$ & POLRI & 1,05 & 0,00 & 0,00 & At Risk \\
\hline 86 & 1JY1UE2A & $\begin{array}{l}\text { EXIM BANK } \\
\text { KOREA }\end{array}$ & $\begin{array}{l}\text { PENGADAAN AREA TRAFFIC } \\
\text { MONITORING SYSTEM (ATMS) APP } \\
2009 \text { POLRI }\end{array}$ & 01-Feb-17 & 01-Jun-19 & USD & $8.498 .000,00$ & $6.547 .791,64$ & $1.950 .208,36$ & POLRI & 1,03 & 0,77 & 0,75 & $\begin{array}{l}\text { Behind } \\
\text { Schedule }\end{array}$ \\
\hline 87 & 1QMV8AGA & $\begin{array}{l}\text { PT. BNI- } \\
\text { SINGAPORE }\end{array}$ & $\begin{array}{l}\text { PENGADAAN ALSERSE PENYELIDIKAN } \\
\text { ALOKASI TAHUN } 2009\end{array}$ & 08-Feb-17 & 08-Aug-19 & USD & $11.024 .767,75$ & $3.072 .604,50$ & $7.952 .163,25$ & POLRI & 0,95 & 0,28 & 0,29 & At Risk \\
\hline 88 & 1RYHC26A & $\begin{array}{l}\text { PT. BNI- } \\
\text { SINGAPORE }\end{array}$ & $\begin{array}{l}\text { Pengadaan Alserse Penyidikan Alokasi } \\
2009\end{array}$ & 08-Feb-17 & 08-Aug-19 & USD & $18.667 .610,75$ & $5.244 .907,50$ & $13.422 .703,25$ & POLRI & 0,96 & 0,28 & 0,29 & At Risk \\
\hline 89 & 1116F8FA & IFAD & $\begin{array}{l}\text { INTEGRATED PARTICIPATORY } \\
\text { DEVELOPMENT AND MANAGEMENT } \\
\text { OF IRRIGATION PROJECT } \\
\end{array}$ & 13-Feb-17 & 30-Sep-23 & EUR & $93.150 .000,00$ & 3.493.929,61 & $89.656 .070,39$ & KEMEN PU \& PERA & 0,36 & 0,04 & 0,10 & At Risk \\
\hline 90 & 1SDVQT1A & BBVAIT & Pengadaan Torpedo A244S Mod. 3 & 10-Mar-17 & 30-Jun-20 & EUR & $4.110 .557,50$ & 0,00 & $4.110 .557,50$ & KEMHAN & 0,49 & 0,00 & 0,00 & $\begin{array}{l}\text { Behind } \\
\text { Schedule }\end{array}$ \\
\hline 91 & 1ELURJQA & $\begin{array}{l}\text { BANK } \\
\text { MANDIRI } \\
\text { SIN }\end{array}$ & $\begin{array}{l}\text { PENGADAAN PERALATAN PUSAT } \\
\text { LABORATORIUM FORENSIK } \\
\text { (PUSLABFOR) DK } 2011\end{array}$ & 27-Mar-17 & 27-Jul-19 & USD & $25.498 .059,45$ & 0,00 & $25.498 .059,45$ & POLRI & 0,76 & 0,00 & 0,00 & At Risk \\
\hline 92 & 1SYVA92A & JICA & $\begin{array}{l}\text { KOMERING IRRIGATION PROJECT } \\
\text { (PHASE 3) }\end{array}$ & 30-Mar-17 & 27-Jul-25 & JPY & $15.896 .000 .000,00$ & 0,00 & $15.896 .000 .000,00$ & KEMEN PU \& PERA & 0,24 & 0,00 & 0,00 & $\begin{array}{l}\text { Behind } \\
\text { Schedule }\end{array}$ \\
\hline 93 & $17 \mathrm{HCS} 2 \mathrm{YA}$ & JICA & $\begin{array}{l}\text { BALI BEACH CONSERVATION PROJECT } \\
\text { (PHASE 2) }\end{array}$ & 30-Mar-17 & 27-Jul-25 & JPY & $9.855 .000 .000,00$ & 0,00 & $9.855 .000 .000,00$ & KEMEN PU \& PERA & 0,24 & 0,00 & 0,00 & $\begin{array}{l}\text { Behind } \\
\text { Schedule }\end{array}$ \\
\hline 94 & 1HJ95NBA & JICA & $\begin{array}{l}\text { RENTANG IRRIGATION } \\
\text { MODERNIZATION PROJECT }\end{array}$ & 30-Mar-17 & 27-Jul-26 & JPY & $48.237 .000 .000,00$ & 0,00 & $48.237 .000 .000,00$ & KEMEN PU \& PERA & 0,21 & 0,00 & 0,00 & $\begin{array}{l}\text { Behind } \\
\text { Schedule }\end{array}$ \\
\hline 95 & 14CYD3PA & $\begin{array}{l}\text { PT. BNI- } \\
\text { SINGAPORE }\end{array}$ & $\begin{array}{l}\text { Pengadaan Peralatan Alat } \\
\text { Laboratorium Forensik (Allabfor) } \\
\text { Stasioner Alokasi Tahun } 2008\end{array}$ & 05-Apr-17 & 05-Dec-19 & USD & $5.099 .984,14$ & $2.434 .396,00$ & $2.665 .588,14$ & POLRI & 0,83 & 0,48 & 0,58 & $\begin{array}{l}\text { Behind } \\
\text { Schedule }\end{array}$ \\
\hline 96 & 1KPJQ47A & $\begin{array}{l}\text { PT. BNI- } \\
\text { SINGAPORE }\end{array}$ & $\begin{array}{l}\text { PENGADAAN ALLABFOR STASIONER } \\
\text { ALOKASI TAHUN } 2009\end{array}$ & 05-Apr-17 & 05-Dec-19 & USD & $5.099 .947,36$ & $1.586 .174,25$ & $3.513 .773,11$ & POLRI & 0,84 & 0,31 & 0,37 & $\begin{array}{l}\text { Behind } \\
\text { Schedule }\end{array}$ \\
\hline 97 & 1ZZ7LGXA & IBRD & $\begin{array}{l}\text { DAM OPERATIONAL IMPROVEMENT } \\
\text { AND SAFETY PORJECT (DOISP) PHASE } \\
\text { II/ADDITIONAL FINANCING FOR DAM } \\
\text { OPERATIONAL IMPROVEMENT AND } \\
\text { SAFETY PROJECT }\end{array}$ & 09-May-17 & 30-Jun-23 & USD & $125.000 .000,00$ & $11.876 .747,39$ & 113.123.252,61 & KEMEN PU \& PERA & 0,32 & 0,10 & 0,29 & At Risk \\
\hline 98 & 1LF9UFAA & IBRD & $\begin{array}{l}\text { REGIONAL INFRASTRUCTURE } \\
\text { DEVELOPMENT FUND PROJECT }\end{array}$ & 12-May-17 & 31-Dec-20 & USD & $100.000 .000,00$ & $11.581 .276,36$ & $88.418 .723,64$ & PT. SM I & 0,54 & 0,12 & 0,22 & At Risk \\
\hline
\end{tabular}




\begin{tabular}{|c|c|c|c|c|c|c|c|c|c|c|c|c|c|c|}
\hline No & $\begin{array}{l}\text { REGISTER } \\
\text { NO }\end{array}$ & $\begin{array}{l}\text { PEMBERI } \\
\text { PINJAMAN }\end{array}$ & NAMA PROYEK & $\begin{array}{l}\text { TANGGAL } \\
\text { LOAN }\end{array}$ & $\begin{array}{l}\text { BATAS } \\
\text { PENARIKAN } \\
\text { TERAKHIR }\end{array}$ & $\begin{array}{l}\text { MATA } \\
\text { UANG }\end{array}$ & NILAI PINJAMAN & $\begin{array}{l}\text { PINJAMAN YANG } \\
\text { TELAH DITARIK }\end{array}$ & $\begin{array}{l}\text { SISA PINJAMAN } \\
\text { YANG BELUM } \\
\text { DITARIK }\end{array}$ & $\begin{array}{l}\text { K/L PELAKSANA } \\
\text { PROYEK }\end{array}$ & ETR & DR & PV & KET. PV \\
\hline 99 & 1NQ47EHA & IDB & $\begin{array}{l}\text { Development of Trans South-South } \\
\text { Java Road Project }\end{array}$ & 16-May-17 & 16-Aug-21 & USD & $235.000 .000,00$ & 0,00 & $235.000 .000,00$ & KEMEN PU \& PERA & 0,43 & 0,00 & 0,00 & $\begin{array}{l}\text { Behind } \\
\text { Schedule }\end{array}$ \\
\hline 100 & 1SMHNPCA & IDB & $\begin{array}{l}\text { Development of Trans South-South } \\
\text { Java Road Project }\end{array}$ & 16-May-17 & 14-Aug-22 & USD & $15.000 .000,00$ & 0,00 & $15.000 .000,00$ & KEMEN PU \& PERA & 0,34 & 0,00 & 0,00 & $\begin{array}{l}\text { Behind } \\
\text { Schedule }\end{array}$ \\
\hline 101 & 1YQYPA9A & $\begin{array}{l}\text { CREDIT } \\
\text { AGRICOLE } \\
\text { CIB } \\
\end{array}$ & $\begin{array}{l}\text { PENGADAAN RUDAL ARTILERI } \\
\text { PERTAHANAN UDARA TNI AD }\end{array}$ & 22-May-17 & 28-Feb-21 & USD & $170.000 .000,00$ & $50.000 .000,00$ & $120.000 .000,00$ & KEMHAN & 0,52 & 0,29 & 0,57 & $\begin{array}{l}\text { Behind } \\
\text { Schedule }\end{array}$ \\
\hline 102 & 1GWAFRLA & IBRD & $\begin{array}{l}\text { Increasing PT Indonesia Infrastructure } \\
\text { Finance Financing Capacity in } \\
\text { Accelarating Infrastructure } \\
\text { Development in Indonesia/ Additional } \\
\text { Financing for Indonesia Infrastructure } \\
\text { Finance Facility Project }\end{array}$ & 29-May-17 & 28-Feb-22 & USD & $200.000 .000,00$ & 20.794.343,94 & $179.205 .656,06$ & PT. SMI & 0,40 & 0,10 & 0,26 & At Risk \\
\hline 103 & 1XH37L2A & AllB & $\begin{array}{l}\text { Dam Operational Improvement and } \\
\text { Safety Project (DOISP) Phase II }\end{array}$ & 29-May-17 & 30-Jun-23 & USD & $125.000 .000,00$ & $11.876 .747,39$ & $113.123 .252,61$ & DITJEN S.D.AIR-PU & 0,32 & 0,10 & 0,30 & $\begin{array}{l}\text { Behind } \\
\text { Schedule }\end{array}$ \\
\hline 104 & 145E6FTA & AllB & $\begin{array}{l}\text { REGIONAL INFRASTRUCTURE } \\
\text { DEVELOPMENT FUND PROJECT (RIDF) }\end{array}$ & 07-Jun-17 & 31-Dec-20 & USD & $100.000 .000,00$ & $11.571 .675,30$ & $88.428 .324,70$ & PT. SMI & 0,54 & 0,12 & 0,22 & At Risk \\
\hline 105 & 1 HT9CCSA & $\begin{array}{l}\text { EKSPORTKR } \\
\text { EDITT AS }\end{array}$ & $\begin{array}{l}\text { MEDIUM RANGE MISSILE FOR CAPITAL } \\
\text { AIR DEFENCE AND ITS SUPPORTING }\end{array}$ & 21-Jun-17 & 01-Jan-21 & USD & $101.660 .000,00$ & $79.376 .470,00$ & $22.283 .530,00$ & KEMHAN & 0,57 & 0,78 & 1,36 & $\begin{array}{l}\text { On and } \\
\text { ahead } \\
\text { Schedule }\end{array}$ \\
\hline 106 & 1Q2CFPRA & IBRD & $\begin{array}{l}\text { SOCIAL ASSISTANCE REFORM } \\
\text { PROGRAM }\end{array}$ & 10-Jul-17 & 30-Jun-21 & USD & $200.000 .000,00$ & $120.800 .000,00$ & $79.200 .000,00$ & & 0,48 & 0,60 & 1,26 & $\begin{array}{l}\text { On and } \\
\text { ahead } \\
\text { Schedule }\end{array}$ \\
\hline 107 & 1Z83YQPA & ADB-OF & $\begin{array}{l}\text { INTEGRATED PARTICIPATORY } \\
\text { DEVELOPMENT AND MANAGEMENT } \\
\text { OF IRRIGATION PROGRAM }\end{array}$ & 31-Jul-17 & 30-Jun-23 & USD & $500.000 .000,00$ & $41.650 .000,00$ & $458.350 .000,00$ & KEMEN PU \& PERA & 0,31 & 0,08 & 0,27 & At Risk \\
\hline 108 & 11DDKS1A & ADB-OF & $\begin{array}{l}\text { INTEGRATED PARTICIPATORY } \\
\text { DEVELOPMENT AND MANAGEMENT } \\
\text { OF IRRIGATION PROGRAM } \\
\end{array}$ & 31-Jul-17 & 30-Jun-23 & USD & $100.000 .000,00$ & $8.350 .000,00$ & $91.650 .000,00$ & KEMEN PU \& PERA & 0,31 & 0,08 & 0,27 & At Risk \\
\hline 109 & 1FFPYVVA & $\begin{array}{l}\text { PT BNI } \\
\text { TOKYO } \\
\text { BRANCH } \\
\end{array}$ & $\begin{array}{l}\text { PROCUREMENT OF EDUCATION } \\
\text { TECHNOLOGY INDONESIA NATIONAL } \\
\text { POLICE }\end{array}$ & 08-Aug-17 & 08-Oct-19 & USD & $12.707 .508,50$ & $11.654 .299,10$ & $1.053 .209,40$ & POLRI & 0,87 & 0,92 & 1,05 & $\begin{array}{l}\text { On and } \\
\text { ahead } \\
\text { Schedule }\end{array}$ \\
\hline 110 & 1GQ1HVJA & $\begin{array}{l}\text { CREDIT } \\
\text { AGRICOLE } \\
\text { CIB }\end{array}$ & 155MM Self-Propelled Gun Howitzer & 06-Sep-17 & 06-Dec-20 & EUR & $100.533 .750,00$ & $21.775 .066,66$ & $78.758 .683,34$ & KEMHAN & 0,45 & 0,22 & 0,48 & $\begin{array}{l}\text { Behind } \\
\text { Schedule }\end{array}$ \\
\hline 111 & 127ML9A & $\begin{array}{l}\text { PT. BNI- } \\
\text { HONG } \\
\text { KONG }\end{array}$ & $\begin{array}{l}\text { PROCUREMENT OF FORENSIC LAB } \\
\text { EQUIPMENT FOR INDONESIA } \\
\text { NATIONAL POLICE }\end{array}$ & 14-Sep-17 & 14-Jan-20 & USD & $25.499 .984,74$ & 0,00 & $25.499 .984,74$ & POLRI & 0,75 & 0,00 & 0,00 & At Risk \\
\hline 112 & 1JWHPTXA & $\begin{array}{l}\text { PT MANDIRI } \\
\text { CAYMAN IS }\end{array}$ & $\begin{array}{l}\text { ROCKET DAN SPECIAL TACTICAL FIELD } \\
\text { ARTILER VEHICLES AVRMD AND } \\
\text { AVRFCU }\end{array}$ & 20-Sep-17 & 20-Nov-20 & USD & $321.300 .000,00$ & $155.953 .815,83$ & $165.346 .184,17$ & KEMHAN & 0,46 & 0,49 & 1,05 & $\begin{array}{l}\text { On and } \\
\text { ahead } \\
\text { Schedule }\end{array}$ \\
\hline 113 & 1QW5JMNA & $\begin{array}{l}\text { CZECH } \\
\text { EXPORT } \\
\text { BANK } \\
\end{array}$ & $\begin{array}{l}\text { Amphibious Bridging and Ferrying Set } \\
\text { (Alat Penyeberangan Amphibious } \\
\text { Ponton Set) }\end{array}$ & 29-Sep-17 & 29-Mar-21 & USD & $130.474 .830,00$ & $37.590 .154,50$ & $92.884 .675,50$ & KEMHAN & 0,50 & 0,29 & 0,58 & $\begin{array}{l}\text { Behind } \\
\text { Schedule }\end{array}$ \\
\hline 114 & 1KJ1RFUA & $\begin{array}{l}\text { PT. BNI- } \\
\text { SINGAPORE }\end{array}$ & $\begin{array}{l}\text { HELIKOPTER DENGAN PERLENGKAPAN } \\
\text { PENDUKUNG PROGRAM KE TA } 2008\end{array}$ & 20-Oct-17 & 20-Oct-19 & USD & $9.350 .000,00$ & $2.793 .769,22$ & $6.556 .230,78$ & POLRI & 0,82 & 0,30 & 0,36 & $\begin{array}{l}\text { Behind } \\
\text { Schedule }\end{array}$ \\
\hline 115 & 1WLVADRA & BBVAIT & Procurement of Caliber $30 \mathrm{MM}$ Gun & 25-Oct-17 & $31-$ Oct-20 & EUR & $19.346 .850,00$ & $7.966 .350,00$ & $11.380 .500,00$ & KEMHAN & 0,42 & 0,41 & 0,98 & $\begin{array}{l}\text { Behind } \\
\text { Schedule }\end{array}$ \\
\hline
\end{tabular}




\begin{tabular}{|c|c|c|c|c|c|c|c|c|c|c|c|c|c|c|}
\hline No & $\begin{array}{l}\text { REGISTER } \\
\text { NO }\end{array}$ & $\begin{array}{l}\text { PEMBERI } \\
\text { PINJAMAN }\end{array}$ & NAMA PROYEK & $\begin{array}{l}\text { TANGGAL } \\
\text { LOAN }\end{array}$ & $\begin{array}{c}\text { BATAS } \\
\text { PENARIKAN } \\
\text { TERAKHIR }\end{array}$ & $\begin{array}{l}\text { MATA } \\
\text { UANG }\end{array}$ & NILAI PINJAMAN & $\begin{array}{l}\text { PINJAMAN YANG } \\
\text { TELAH DITARIK }\end{array}$ & $\begin{array}{l}\text { SISA PINJAMAN } \\
\text { YANG BELUM } \\
\text { DITARIK }\end{array}$ & $\begin{array}{l}\text { K/L PELAKSANA } \\
\text { PROYEK }\end{array}$ & ETR & DR & PV & KET. PV \\
\hline 116 & 142FXVJA & BBVAIT & Procurement of Caliber $40 \mathrm{MM}$ Gun & 25-Oct-17 & $31-$ Oct-20 & EUR & $24.184 .200,00$ & $9.958 .200,00$ & $14.226 .000,00$ & KEMHAN & 0,42 & 0,41 & 0,98 & $\begin{array}{l}\text { Behind } \\
\text { Schedule }\end{array}$ \\
\hline 117 & 19QWZABA & BBVAIT & Procurement of Torpedo Black Shark & $25-O c t-17$ & $28-F e b-21$ & EUR & $18.893 .927,27$ & 0,00 & $18.893 .927,27$ & KEMHAN & 0,37 & 0,00 & 0,00 & $\begin{array}{l}\text { Behind } \\
\text { Schedule }\end{array}$ \\
\hline 118 & 1R72L86A & BLG & $\begin{array}{l}\text { Pengadaan } 6 \text { Pesawat Latih Grob } \\
\text { G120TP dan ILS Kemhan }\end{array}$ & 30-Oct-17 & 30-Jan-20 & EUR & $21.335 .000,00$ & $19.714 .000,00$ & $1.621 .000,00$ & KEMHAN & 0,70 & 0,92 & 1,31 & $\begin{array}{l}\text { On and } \\
\text { ahead } \\
\text { Schedule }\end{array}$ \\
\hline 119 & 17T39EMA & $\mathrm{KfW}$ & $\begin{array}{l}\text { Hasanuddin University Hospital } \\
\text { Development Project }\end{array}$ & 01-Nov-17 & 15-Nov-22 & EUR & $30.000 .000,00$ & $495.945,00$ & $29.504 .055,00$ & KEMENRISTEKDIKTI & 0,20 & 0,02 & 0,08 & At Risk \\
\hline 120 & 1FAHSUWA & JICA & $\begin{array}{l}\text { DEVELOPMENT OF WORLD CLASS } \\
\text { UNIVERSITY WITH SOCIO } \\
\text { ENTREPRENEURIAL SPIRIT AT } \\
\text { UNIVERSITAS GADJAH MADA }\end{array}$ & 15-Nov-17 & 13-Mar-25 & JPY & $8.309 .000 .000,00$ & $223.737 .302,00$ & $8.085 .262 .698,00$ & KEMENRISTEKDIKTI & 0,19 & 0,03 & 0,15 & At Risk \\
\hline 121 & 1AVH2LAA & JICA & $\begin{array}{l}\text { PATIMBAN PORT DEVELOPMENT } \\
\text { PROJECT (I) }\end{array}$ & 15-Nov-17 & 13-Mar-26 & JPY & $\begin{array}{r}118.906 .000 .000,0 \\
0\end{array}$ & $20.268 .218 .393,00$ & $98.637 .781 .607,00$ & KEMENHUB & 0,16 & 0,17 & 1,05 & $\begin{array}{l}\text { On and } \\
\text { ahead } \\
\text { Schedule }\end{array}$ \\
\hline 122 & 144PPR5A & $\begin{array}{l}\text { PT. BNI- } \\
\text { HONG } \\
\text { KONG }\end{array}$ & $\begin{array}{l}\text { Maintenance, Repair and Overhaul of } \\
\text { KRI Cakra-401 Submarine }\end{array}$ & 29-Nov-17 & 29-Jul-20 & USD & $34.000 .000,00$ & $24.000 .000,00$ & $10.000 .000,00$ & KEMHAN & 0,46 & 0,71 & 1,52 & $\begin{array}{l}\text { On and } \\
\text { ahead } \\
\text { Schedule }\end{array}$ \\
\hline 123 & 1HG72SWA & IBRD & $\begin{array}{l}\text { NATIONAL AFFORDABLE HOUSING } \\
\text { PROGRAM PROJECT }\end{array}$ & 30-Nov-17 & 31-Mar-21 & USD & $450.000 .000,00$ & $41.400 .800,00$ & $408.599 .200,00$ & KEMEN PU \& PERA & 0,45 & 0,09 & 0,20 & At Risk \\
\hline 124 & 17PRJ1UA & $\begin{array}{l}\text { BNP } \\
\text { PARIBAS, } \\
\text { PARIS } \\
\end{array}$ & $\begin{array}{l}\text { Penangkis Serangan Udara (PSU) } \\
\text { Program Lembaga Penjamin Kredit } \\
\text { Ekspor TA } 2016\end{array}$ & 29-Dec-17 & 29-Jun-21 & CHF & $101.946 .786,00$ & 29.984.349,00 & $71.962 .437,00$ & KEMHAN & 0,25 & 0,29 & 1,20 & $\begin{array}{l}\text { On and } \\
\text { ahead } \\
\text { Schedule }\end{array}$ \\
\hline 125 & 191SRJYA & IFAD & $\begin{array}{l}\text { RURAL EMPOWERMENT AND } \\
\text { AGRICULTURAL DEVELOPMENT } \\
\text { PROGRAMME SCALING-UP INITIATIVE } \\
\text { (READSI) } \\
\text { (REIA }\end{array}$ & 08-Jan-18 & 30-Sep-23 & USD & $39.885 .000,00$ & $2.500 .000,00$ & $37.385 .000,00$ & KEMENTAN & 0,26 & 0,06 & 0,24 & At Risk \\
\hline 126 & 1SFVCKQA & $\begin{array}{l}\text { EXIM BANK } \\
\text { OF CHINA }\end{array}$ & $\begin{array}{l}\text { Preferential Buyer Credit Loan } \\
\text { Agreement On Toll Road Development } \\
\text { of Cileunyi-Sumedang-Dawuan Phase } \\
\text { III Project }\end{array}$ & 07-May-18 & $18-0 c t-23$ & USD & $130.387 .425,76$ & $9.477 .117,79$ & $120.910 .307,97$ & KEMEN-PU & 0,14 & 0,07 & 0,52 & $\begin{array}{l}\text { Behind } \\
\text { Schedule }\end{array}$ \\
\hline 127 & 1HS4NF9A & AllB & $\begin{array}{l}\text { STRATEGIC IRRIGATION } \\
\text { MODERNIZATION AND URGENT } \\
\text { REHABILITATION PROJECT }\end{array}$ & 11-Jul-18 & 30-Jun-24 & USD & $250.000 .000,00$ & $5.988 .873,41$ & 244.011.126,59 & DITJEN S.D.AIR-PU & 0,15 & 0,02 & 0,16 & At Risk \\
\hline 128 & 1B4ND8ZA & IBRD & $\begin{array}{l}\text { INDONESIA SUPPORTING PRIMARY } \\
\text { HEALTH CARE REFORM } \\
\text { PROGRAM/INDONESIA SUPPORTING } \\
\text { PRIMARY AND REFERRAL HEALTH } \\
\text { CARE REFORM PROGRAM } \\
\end{array}$ & 17-Jul-18 & 30-Apr-24 & USD & $150.000 .000,00$ & $37.500 .000,00$ & $112.500 .000,00$ & DITJEN PEL. KES. & 0,13 & 0,25 & 1,92 & $\begin{array}{l}\text { On and } \\
\text { ahead } \\
\text { Schedule }\end{array}$ \\
\hline 129 & 1NF3PM6A & IBRD & $\begin{array}{l}\text { Strategic Irrigation Modernization and } \\
\text { Urgent Rehabilitation Project }\end{array}$ & 25-Jul-18 & 30-Jun-24 & USD & $250.000 .000,00$ & $5.988 .873,42$ & $244.011 .126,58$ & DITJEN S.D.AIR-PU & 0,15 & 0,02 & 0,16 & At Risk \\
\hline 130 & 1VY4JPRA & IBRD & $\begin{array}{l}\text { Investing in Nutrition and Early Years } \\
\text { Program }\end{array}$ & 01-Aug-18 & 30-Apr-22 & USD & $400.000 .000,00$ & 0,00 & $400.000 .000,00$ & & 0,21 & 0,00 & 0,00 & $\begin{array}{l}\text { Behind } \\
\text { Schedule }\end{array}$ \\
\hline 131 & 1CPUK3GA & IBRD & $\begin{array}{l}\text { National Urban Water Supply Project } \\
\text { (NUWSP) }\end{array}$ & 02-Aug-18 & 31-Dec-22 & USD & $100.000 .000,00$ & $1.000 .000,00$ & $99.000 .000,00$ & & 0,20 & 0,01 & 0,05 & At Risk \\
\hline
\end{tabular}




\begin{tabular}{|c|c|c|c|c|c|c|c|c|c|c|c|c|c|c|}
\hline No & $\begin{array}{l}\text { REGISTER } \\
\text { NO }\end{array}$ & $\begin{array}{l}\text { PEMBERI } \\
\text { PINJAMAN }\end{array}$ & NAMA PROYEK & $\begin{array}{l}\text { TANGGAL } \\
\text { LOAN }\end{array}$ & $\begin{array}{l}\text { BATAS } \\
\text { PENARIKAN } \\
\text { TERAKHIR }\end{array}$ & $\begin{array}{l}\text { MATA } \\
\text { UANG }\end{array}$ & NILAI PINJAMAN & $\begin{array}{l}\text { PINJAMAN YANG } \\
\text { TELAH DITARIK }\end{array}$ & $\begin{array}{l}\text { SISA PINJAMAN } \\
\text { YANG BELUM } \\
\text { DITARIK }\end{array}$ & $\begin{array}{l}\text { K/L PELAKSANA } \\
\text { PROYEK }\end{array}$ & ETR & DR & PV & KET. PV \\
\hline 132 & 164RS1QA & $\begin{array}{l}\text { NATIXIS } \\
\text { BANQUE }\end{array}$ & $\begin{array}{l}\text { DEVELOPMENT OF MARITIME } \\
\text { METEOROLOGICAL INFORMATION } \\
\text { SYSTEM }\end{array}$ & 13-Aug-18 & 31-Jul-25 & EUR & $43.000 .000,00$ & 0,00 & $43.000 .000,00$ & BMKG & $-0,01$ & 0,00 & 0,00 & $\begin{array}{l}\text { Behind } \\
\text { Schedule }\end{array}$ \\
\hline 133 & 18AP2S4A & $\begin{array}{l}\text { BANK } \\
\text { MANDIRI } \\
\text { SIN } \\
\end{array}$ & $\begin{array}{l}\text { Sabhara Armoured Water Cannon } \\
\text { (AWC) TA } 2016\end{array}$ & 28-Sep-18 & 28-Jun-20 & USD & 16.999.111,27 & $6.751 .054,59$ & $10.248 .056,68$ & POLRI & 0,35 & 0,40 & 1,14 & $\begin{array}{l}\text { On and } \\
\text { ahead } \\
\text { Schedule }\end{array}$ \\
\hline 134 & 15Q9AK2A & $\begin{array}{l}\text { BANK } \\
\text { MANDIRI } \\
\text { SIN } \\
\end{array}$ & APC Multifungsi Brimob TA 2016 & 28-Sep-18 & 28-Jun-20 & USD & $33.999 .753,50$ & 0,00 & $33.999 .753,50$ & POLRI & 0,35 & 0,00 & 0,00 & $\begin{array}{l}\text { Behind } \\
\text { Schedule }\end{array}$ \\
\hline 135 & 1VQQQ95A & $\begin{array}{l}\text { PT MANDIRI } \\
\text { HONGKONG }\end{array}$ & PERALATAN KHUSUS SATWA TA 2016 & 28-Sep-18 & 28-Jul-20 & USD & $12.748 .725,00$ & 0,00 & $12.748 .725,00$ & POLRI & 0,26 & 0,00 & 0,00 & $\begin{array}{l}\text { Behind } \\
\text { Schedule }\end{array}$ \\
\hline 136 & 14JC47XA & $\begin{array}{l}\text { BANK } \\
\text { MANDIRI } \\
\text { SIN } \\
\end{array}$ & Kendaraan Patroli Cepat Sabhara & 28-Sep-18 & $28-O c t-20$ & USD & $28.029 .002,69$ & 0,00 & $28.029 .002,69$ & POLRI & 0,29 & 0,00 & 0,00 & $\begin{array}{l}\text { Behind } \\
\text { Schedule }\end{array}$ \\
\hline 137 & 16GUAH6A & $\begin{array}{l}\text { BANK } \\
\text { MANDIRI } \\
\text { SIN } \\
\end{array}$ & $\begin{array}{l}\text { PROCUREMENT OF IT NETWORK } \\
\text { SECURITY EQUIPMENTS }\end{array}$ & 28-Sep-18 & 28-Dec-20 & USD & $8.498 .432,60$ & $7.933 .837,95$ & $564.594,65$ & POLRI & 0,27 & 0,93 & 3,47 & $\begin{array}{l}\text { On and } \\
\text { ahead } \\
\text { Schedule } \\
\end{array}$ \\
\hline 138 & 1NU7QSVA & $\begin{array}{l}\text { BANK } \\
\text { MANDIRI } \\
\text { SIN }\end{array}$ & $\begin{array}{l}\text { PROCUREMENT OF SISKOM } \\
\text { (COMMUNICATION SYSTEM) PAPUA, } \\
\text { WEST PAPUA, MALUKU AND NORTH } \\
\text { MALUKU }\end{array}$ & 28-Sep-18 & 28-Jan-21 & USD & $59.498 .368,00$ & $34.124 .912,60$ & $25.373 .455,40$ & POLRI & 0,26 & 0,57 & 2,22 & $\begin{array}{l}\text { On and } \\
\text { ahead } \\
\text { Schedule }\end{array}$ \\
\hline 139 & 1DZKYRBA & $\begin{array}{l}\text { BANK } \\
\text { MANDIRI } \\
\text { SIN }\end{array}$ & $\begin{array}{l}\text { PROCUREMENT OF INTEL } \\
\text { EQUIPMENTS }\end{array}$ & 28-Sep-18 & 28-Jan-21 & USD & $42.313 .476,85$ & $8.149 .585,15$ & $34.163 .891,70$ & POLRI & 0,25 & 0,19 & 0,77 & $\begin{array}{l}\text { Behind } \\
\text { Schedule }\end{array}$ \\
\hline 140 & 14QPDHPA & $\begin{array}{l}\text { CREDIT } \\
\text { AGRICOLE } \\
\text { CIB } \\
\end{array}$ & $\begin{array}{l}\text { Upgrade Fire Control System Exocet } \\
\text { Block } 2 \text { to Block } 3\end{array}$ & 08-Oct-18 & 08-Jun-23 & EUR & $35.214 .565,00$ & 0,00 & $35.214 .565,00$ & KEMHAN & 0,02 & 0,00 & 0,00 & $\begin{array}{l}\text { Behind } \\
\text { Schedule }\end{array}$ \\
\hline 141 & 1M1JWRAA & IBRD & $\begin{array}{l}\text { INTEGRATED INFRASTRUCTURE } \\
\text { DEVELOPMENT FOR NATIONAL } \\
\text { TOURISM STRATEGIC AREAS } \\
\text { (INDONESIA TOURISM DEVELOPMENT } \\
\text { PROJECT) }\end{array}$ & 24-Oct-18 & 31-Dec-23 & USD & $300.000 .000,00$ & 0,00 & $300.000 .000,00$ & BPIW PUPR & 0,12 & 0,00 & 0,00 & $\begin{array}{l}\text { Behind } \\
\text { Schedule }\end{array}$ \\
\hline 142 & 1M8B4A8A & JICA & $\begin{array}{l}\text { Construction of Jakarta Mass Rapid } \\
\text { Transit Project (Phase 2) (I) }\end{array}$ & 24-Oct-18 & 23-Apr-25 & JPY & $70.021 .000 .000,00$ & 0,00 & $70.021 .000 .000,00$ & $\begin{array}{l}\text { DITJEN } \\
\text { PERKERETAAPIA }\end{array}$ & 0,03 & 0,00 & 0,00 & $\begin{array}{l}\text { Behind } \\
\text { Schedule }\end{array}$ \\
\hline 143 & 1BUY9N3A & IBRD & $\begin{array}{l}\text { PROGRAM TO ACCELERATE AGRARIAN } \\
\text { REFORM (ONE MAP PROJECT) }\end{array}$ & 26-Oct-18 & 31-Oct-23 & USD & $200.000 .000,00$ & $3.744 .948,13$ & $196.255 .051,87$ & DITJEN AGRARIA & 0,13 & 0,02 & 0,15 & At Risk \\
\hline 144 & 1P2DQW5A & $\begin{array}{l}\text { EXIM BANK } \\
\text { KOREA }\end{array}$ & $\begin{array}{l}\text { Engineering Services Project for } \\
\text { Multipurpose Dams, Rivers, and } \\
\text { Coastal }\end{array}$ & 30-Oct-18 & 15-May-22 & USD & $31.705 .000,00$ & 0,00 & $31.705 .000,00$ & KEMEN PU \& PERA & 0,11 & 0,00 & 0,00 & $\begin{array}{l}\text { Behind } \\
\text { Schedule }\end{array}$ \\
\hline 145 & 1WGFUXVA & $\begin{array}{l}\text { PT BNI } \\
\text { TOKYO } \\
\text { BRANCH } \\
\end{array}$ & $\begin{array}{l}\text { PROCUREMENT OF MISSILE MLRS } \\
\text { AVIBRAS/ASTROS II }\end{array}$ & 02-Nov-18 & 02-Nov-20 & USD & $18.700 .000,00$ & $14.532 .510,44$ & 4.167.489,56 & KEMHAN & 0,33 & 0,78 & 2,37 & $\begin{array}{l}\text { On and } \\
\text { ahead } \\
\text { Schedule }\end{array}$ \\
\hline 146 & 1PYJBXHA & $\begin{array}{l}\text { PT MANDIRI } \\
\text { HONGKONG }\end{array}$ & $\begin{array}{l}\text { Procurement of KBR Equipment for } \\
\text { Indonesian National Police T.A. } 2016\end{array}$ & 05-Dec-18 & 05-Oct-20 & USD & $12.725 .945,00$ & $9.647 .304,50$ & $3.078 .640,50$ & POLRI & 0,23 & 0,76 & 3,32 & $\begin{array}{l}\text { On and } \\
\text { ahead } \\
\text { Schedule }\end{array}$ \\
\hline 147 & 1QPPEXGA & $\begin{array}{l}\text { PT MANDIRI } \\
\text { CAYMAN IS }\end{array}$ & $\begin{array}{l}\text { AIRCRAFT SPARE PARTS } \\
\text { MAINTENANCE }\end{array}$ & 06-Dec-18 & 06-Jun-20 & USD & $8.499 .065,00$ & $3.794 .928,18$ & $4.704 .136,82$ & POLRI & 0,18 & 0,45 & 2,54 & $\begin{array}{l}\text { On and } \\
\text { ahead } \\
\text { Schedule }\end{array}$ \\
\hline 148 & 12ZZV7AA & $\begin{array}{l}\text { PT MANDIRI } \\
\text { CAYMAN IS }\end{array}$ & $\begin{array}{l}\text { Technology System of Budgeting } \\
\text { Management }\end{array}$ & 06-Dec-18 & 06-Dec-20 & USD & $12.725 .959,06$ & 0,00 & $12.725 .959,06$ & POLRI & 0,16 & 0,00 & 0,00 & $\begin{array}{l}\text { Behind } \\
\text { Schedule }\end{array}$ \\
\hline
\end{tabular}




\begin{tabular}{|c|c|c|c|c|c|c|c|c|c|c|c|c|c|c|}
\hline No & $\begin{array}{l}\text { REGISTER } \\
\text { NO }\end{array}$ & $\begin{array}{l}\text { PEMBERI } \\
\text { PINJAMAN }\end{array}$ & NAMA PROYEK & $\begin{array}{l}\text { TANGGAL } \\
\text { LOAN }\end{array}$ & $\begin{array}{l}\text { BATAS } \\
\text { PENARIKAN } \\
\text { TERAKHIR }\end{array}$ & $\begin{array}{l}\text { MATA } \\
\text { UANG }\end{array}$ & NILAI PINJAMAN & $\begin{array}{l}\text { PINJAMAN YANG } \\
\text { TELAH DITARIK }\end{array}$ & $\begin{array}{l}\text { SISA PINJAMAN } \\
\text { YANG BELUM } \\
\text { DITARIK }\end{array}$ & $\begin{array}{l}\text { K/L PELAKSANA } \\
\text { PROYEK }\end{array}$ & ETR & DR & PV & KET. PV \\
\hline 149 & 13P18LTA & $\begin{array}{l}\text { UNICREDIT } \\
\text { BANK } \\
\text { AUSTR } \\
\end{array}$ & $\begin{array}{l}\text { UPGRADING AND MODERNIZATION } \\
\text { OF MEDICAL EQUIPMENT AT RSAU DR } \\
\text { DODY SARJOTO MAKASSAR }\end{array}$ & 10-Dec-18 & $08-O c t-20$ & EUR & $12.500 .000,00$ & $4.376 .823,50$ & $8.123 .176,50$ & KEMHAN & 0,15 & 0,35 & 2,32 & $\begin{array}{l}\text { On and } \\
\text { ahead } \\
\text { Schedule }\end{array}$ \\
\hline 150 & 1LDCQAKA & $\begin{array}{l}\text { UNICREDIT } \\
\text { BANK } \\
\text { AUSTR } \\
\end{array}$ & $\begin{array}{l}\text { UPGRADING MEDICAL EQUIPMENT } \\
\text { FOR NAVAL HOSPITAL DR WAHYU } \\
\text { SLAMET }\end{array}$ & 10-Dec-18 & 12-Jan-21 & EUR & $12.000 .000,00$ & $1.800 .000,00$ & $10.200 .000,00$ & KEMHAN & 0,12 & 0,15 & 1,22 & $\begin{array}{l}\text { On and } \\
\text { ahead } \\
\text { Schedule }\end{array}$ \\
\hline 151 & 1R7APH4A & $\begin{array}{l}\text { PT. BNI- } \\
\text { SINGAPORE }\end{array}$ & Peralatan Cyber & 11-Dec-18 & 11-Jun-20 & USD & $8.493 .030,00$ & 0,00 & $8.493 .030,00$ & POLRI & 0,24 & 0,00 & 0,00 & $\begin{array}{l}\text { Behind } \\
\text { Schedule }\end{array}$ \\
\hline 152 & 12GU9GDA & $\begin{array}{l}\text { PT. BNI- } \\
\text { SINGAPORE }\end{array}$ & Peralatan Security Barrier KSA 2016 & 11-Dec-18 & 11-Dec-20 & USD & $12.718 .422,50$ & $1.594 .573,40$ & $11.123 .849,10$ & POLRI & 0,17 & 0,13 & 0,72 & $\begin{array}{l}\text { Behind } \\
\text { Schedule }\end{array}$ \\
\hline 153 & 1AXPMGJA & $\begin{array}{l}\text { PT. BNI- } \\
\text { SINGAPORE }\end{array}$ & $\begin{array}{l}\text { Pengembangan Industri Teknologi } \\
\text { Kepolisian TA } 2016\end{array}$ & 11-Dec-18 & 11-Dec-20 & USD & $22.082 .701,65$ & 0,00 & $22.082 .701,65$ & POLRI & 0,17 & 0,00 & 0,00 & $\begin{array}{l}\text { Behind } \\
\text { Schedule }\end{array}$ \\
\hline 154 & 175D7J1A & ADB-OF & $\begin{array}{l}\text { Advanced Knowledge and Skills for } \\
\text { Sustainable Growth Project }\end{array}$ & 17-Dec-18 & 30-Jun-24 & USD & $200.000 .000,00$ & 0,00 & $200.000 .000,00$ & KEMENRISTEKDIKTI & 0,04 & 0,00 & 0,00 & $\begin{array}{l}\text { Behind } \\
\text { Schedule }\end{array}$ \\
\hline 155 & 136EFZKA & BNI SEOUL & PUSINAFIS EQUIPMENT PSP 2016 KSA & 04-Mar-19 & 04-Mar-21 & USD & $12.747 .960,00$ & 0,00 & $12.747 .960,00$ & POLRI & 0,16 & 0,00 & 0,00 & $\begin{array}{l}\text { Behind } \\
\text { Schedule }\end{array}$ \\
\hline 156 & 1M1DVXNA & BNI SEOUL & $\begin{array}{l}\text { BRIMOB LONG RANGE PATROL } \\
\text { VEHICLE PSP } 2016 \text { KSA }\end{array}$ & 04-Mar-19 & 04-Jun-21 & USD & $25.499 .717,21$ & 0,00 & $25.499 .717,21$ & POLRI & 0,14 & 0,00 & 0,00 & $\begin{array}{l}\text { Behind } \\
\text { Schedule }\end{array}$ \\
\hline 157 & 1WC2JCRA & SFD & $\begin{array}{l}\text { THE DEVELOPMENT OF UIN MAULANA } \\
\text { MALIK IBRAHIM MALANG PHASE II } \\
\text { EAST JAVA PROJECT }\end{array}$ & 28-Mar-19 & 31-Dec-24 & SAR & $208.500 .000,00$ & 0,00 & $208.500 .000,00$ & DITJEN DIK.ISLAM & $-0,05$ & 0,00 & 0,00 & $\begin{array}{l}\text { Behind } \\
\text { Schedule }\end{array}$ \\
\hline 158 & 1HZXFVGA & SFD & $\begin{array}{l}\text { THE DEVELOPMENT AND UPGRADING } \\
\text { OF THE STATE UNIVERSITY OF } \\
\text { JAKARTA PROJECT PHASE } 2\end{array}$ & 28-Mar-19 & 31-Dec-24 & SAR & $122.625 .000,00$ & 0,00 & $122.625 .000,00$ & KEMENRISTEKDIKTI & 0,01 & 0,00 & 0,00 & $\begin{array}{l}\text { Behind } \\
\text { Schedule }\end{array}$ \\
\hline 159 & 15CE1RCA & $\begin{array}{l}\text { UBS, } \\
\text { ZURICH }\end{array}$ & $\begin{array}{l}\text { PENGADAAN PERALATAN SANDI (PSP } \\
\text { KEMENHAN 2017) }\end{array}$ & 05-Apr-19 & 05-Apr-21 & $\mathrm{CHF}$ & $25.390 .380,60$ & 0,00 & $25.390 .380,60$ & KEMHAN & 0,12 & 0,00 & 0,00 & $\begin{array}{l}\text { Behind } \\
\text { Schedule }\end{array}$ \\
\hline 160 & 1CZG7LLA & $A D B$ & $\begin{array}{l}\text { Financial Market Development and } \\
\text { Inclusion Program - Subprogram } 3\end{array}$ & 03-May-19 & 31-Mar-20 & USD & $500.000 .000,00$ & 0,00 & $500.000 .000,00$ & B K F - KEMENKEU & 0,01 & 0,00 & 0,00 & $\begin{array}{l}\text { Behind } \\
\text { Schedule }\end{array}$ \\
\hline 161 & 1DYTXR1A & IFAD & $\begin{array}{l}\text { YOUTH ENTREPRENEURSHIP AND } \\
\text { EMPLOYMENT SUPPORT SERVICES } \\
\text { PROGRAMME (YESS) }\end{array}$ & 17-Jun-19 & 31-Dec-25 & USD & $55.300 .000,00$ & 0,00 & $55.300 .000,00$ & $\begin{array}{l}\text { BAPENG SDM, } \\
\text { KEMTAN }\end{array}$ & 0,01 & 0,00 & 0,00 & $\begin{array}{l}\text { Behind } \\
\text { Schedule }\end{array}$ \\
\hline
\end{tabular}


POTENSI TAMBAHAN BIAYA (COMMITMENT FEE) KARENA KETERLAMBATAN PROYEK

\begin{tabular}{|c|c|c|c|c|c|c|c|c|c|c|c|c|c|c|c|c|c|}
\hline \multirow[b]{2}{*}{ REGISTER } & \multirow[b]{2}{*}{$\begin{array}{l}\text { KEMENTERIAN / } \\
\text { LEMBAGA }\end{array}$} & \multirow[b]{2}{*}{$\begin{array}{l}\text { PEMBERI } \\
\text { PINJAMAN }\end{array}$} & \multirow[b]{2}{*}{ NAMA PROYEK } & \multirow[b]{2}{*}{$\begin{array}{l}\text { TANGGAL } \\
\text { LOAN }\end{array}$} & \multirow[b]{2}{*}{$\begin{array}{l}\text { TANGGAL } \\
\text { EFEKTIF }\end{array}$} & \multirow[b]{2}{*}{$\begin{array}{c}\text { BATAS } \\
\text { PENARIKAN } \\
\text { TERAKHIR }\end{array}$} & \multirow[b]{2}{*}{$\begin{array}{l}\text { MATA } \\
\text { UANG }\end{array}$} & \multirow[b]{2}{*}{$\begin{array}{c}\text { NILAI } \\
\text { PINJAMAN }\end{array}$} & \multirow[b]{2}{*}{$\begin{array}{l}\text { COMMIT- } \\
\text { MENT } \\
\text { RATE (\%) }\end{array}$} & \multirow[b]{2}{*}{$\begin{array}{c}\text { TANGGAL } \\
\text { ACUAN } \\
\text { PEMBAYARAN } \\
\text { COMMITMENT } \\
\text { FEE }\end{array}$} & \multirow[b]{2}{*}{$\begin{array}{c}\text { PEMBAYARAN } \\
\text { COMMITMENT } \\
\text { FEE }\end{array}$} & \multirow[b]{2}{*}{ ETR } & \multicolumn{4}{|c|}{ PEMBAYARAN COMMITMENT JIKA PROYEK BERJALAN TEPAT WAKTU } & \multirow{2}{*}{$\begin{array}{c}\text { TAMBAHAN } \\
\text { BIAYA/BIAYA } \\
\text { YANG } \\
\text { SEHARUSNYA } \\
\text { DD EFISIENSI } \\
\text { (COMMITMENT } \\
\text { FEE YANG } \\
\text { DIBAYAR } \\
\text { DIKURANGI } \\
\text { COMMMITMENT } \\
\text { FEE JIKA } \\
\text { PROYEK TEPAT } \\
\text { WAKTU) }\end{array}$} \\
\hline & & & & & & & & & & & & & $\begin{array}{l}\mathrm{DR}=\mathrm{ETR} \\
(\mathrm{PV}=1)\end{array}$ & $\begin{array}{l}\text { KUMULATIF } \\
\text { PENARIKAN }\end{array}$ & $\begin{array}{l}\text { NILAI YANG } \\
\text { BELUM } \\
\text { DITARIK }\end{array}$ & $\begin{array}{c}\text { PEMBAYARAN } \\
\text { COMMITMENT } \\
\text { FEE }\end{array}$ & \\
\hline 1 & 2 & 3 & 4 & 5 & 6 & 7 & 8 & 9 & 10 & 11 & 12 & $\begin{array}{c}13= \\
(11-6) / \\
(7-6)\end{array}$ & 14 & $15=(14 \times 9)$ & $16=(9-15)$ & $17=(16 \times 10)$ & $18=(12-17)$ \\
\hline 1DK59PAA & POLRI & $\begin{array}{l}\text { PT. BNI- } \\
\text { SINGAPORE }\end{array}$ & $\begin{array}{l}\text { HARSUCAD KAPAL } \\
2009\end{array}$ & 13-Oct-16 & 13-Oct-16 & 01-Jul-19 & USD & $2.549 .299,44$ & 0.5 & 13-Apr-17 & $6.444,06$ & 0,18 & 0,18 & $468.186,17$ & $2.081 .113,27$ & $5.260,59$ & $1.183,47$ \\
\hline 1DK59PAA & POLRI & $\begin{array}{l}\text { PT. BNI- } \\
\text { SINGAPORE }\end{array}$ & $\begin{array}{l}\text { HARSUCAD KAPAL } \\
2009\end{array}$ & 13-Oct-16 & 13-Oct-16 & 01-Jul-19 & USD & $2.549 .299,44$ & 0.5 & 13-Oct-17 & $6.479,47$ & 0,37 & 0,37 & $938.944,80$ & $1.610 .354,64$ & $4.092,98$ & $2.386,49$ \\
\hline 1DK59PAA & POLRI & $\begin{array}{l}\text { PT. BNI- } \\
\text { SINGAPORE }\end{array}$ & $\begin{array}{l}\text { HARSUCAD KAPAL } \\
2009\end{array}$ & 13-Oct-16 & 13-Oct-16 & 01-Jul-19 & USD & $2.549 .299,44$ & 0.5 & 13-Apr-18 & $6.406,34$ & 0,55 & 0,55 & $1.407 .130,97$ & $1.142 .168,47$ & $2.887,15$ & $3.519,19$ \\
\hline 1DK59PAA & POLRI & $\begin{array}{l}\text { PT. BNI- } \\
\text { SINGAPORE }\end{array}$ & $\begin{array}{l}\text { HARSUCAD KAPAL } \\
2009\end{array}$ & 13-Oct-16 & 13-Oct-16 & 01-Jul-19 & USD & $2.549 .299,44$ & 0.5 & 13-Jun-18 & $2.112,87$ & 0,61 & 0,61 & $1.564 .050,51$ & $985.248,93$ & 967,67 & $1.145,20$ \\
\hline \multirow[t]{2}{*}{ 1DK59PAA } & POLRI & $\begin{array}{l}\text { PT. BNI- } \\
\text { SINGAPORE }\end{array}$ & $\begin{array}{l}\text { HARSUCAD KAPAL } \\
2009\end{array}$ & 13-Oct-16 & 13-Oct-16 & 01-Jul-19 & USD & $2.549 .299,44$ & 0.5 & 13-Dec-18 & $6.220,20$ & 0,80 & 0,80 & $2.034 .809,14$ & $514.490,30$ & $1.804,57$ & $4.415,63$ \\
\hline & & & & & & & & & & & $27.662,94$ & & & & & $15.012,97$ & $12.649,97$ \\
\hline 1NPB3NNA & KEMEN PU \& PERA & IBRD & PAMSIMAS III & 30-Jun-16 & 22-Aug-16 & 31-Dec-20 & USD & $300.000 .000,00$ & 0.25 & 03-Jan-17 & $239.959,01$ & 0,08 & 0,08 & $25.251 .256,28$ & $274.748 .743,72$ & $257.569,53$ & $-17.610,52$ \\
\hline 1NPB3NNA & KEMEN PU \& PERA & IBRD & PAMSIMAS III & 30-Jun-16 & 22-Aug-16 & 31-Dec-20 & USD & $300.000 .000,00$ & 0.25 & 03-Jul-17 & $333.023,97$ & 0,20 & 0,20 & $59.359 .296,48$ & $240.640 .703,52$ & $298.328,54$ & $34.695,43$ \\
\hline 1NPB3NNA & KEMEN PU \& PERA & IBRD & PAMSIMAS III & 30-Jun-16 & 22-Aug-16 & 31-Dec-20 & USD & $300.000 .000,00$ & 0.25 & 02-Jan-18 & $317.283,04$ & 0,31 & 0,31 & $93.844 .221,11$ & $206.155 .778,89$ & $259.812,76$ & $57.470,28$ \\
\hline \multirow[t]{2}{*}{ 1NPB3NNA } & KEMEN PU \& PERA & IBRD & PAMSIMAS III & 30-Jun-16 & 22-Aug-16 & 31-Dec-20 & USD & $300.000 .000,00$ & 0.25 & 02-Jul-18 & $264.114,73$ & 0,43 & 0,43 & $127.952 .261,31$ & \begin{tabular}{|l|l|}
$172.047 .738,69$ \\
\end{tabular} & $213.292,06$ & $50.822,67$ \\
\hline & & & & & & & & & & & $1.154 .380,75$ & & & & & $1.029 .002,89$ & $125.377,86$ \\
\hline 17ТЗ9ЕМА & KEMENRISTEKDIKTI & $\mathrm{KfW}$ & $\begin{array}{l}\text { Hasanuddin } \\
\text { University Hospital }\end{array}$ & 01-Nov-17 & 01-Feb-18 & 15-Nov-22 & EUR & $30.000 .000,00$ & 0.25 & 15-May-18 & $21.666,67$ & 0,06 & 0,06 & $1.767 .734,55$ & $28.232 .265,45$ & $20.389,97$ & $1.276,70$ \\
\hline \multirow[t]{2}{*}{ 17ТЗ9ЕМА } & KEMENRISTEKDIKTI & $\mathrm{KfW}$ & $\begin{array}{l}\text { Hasanuddin } \\
\text { University Hospital }\end{array}$ & 01-Nov-17 & 01-Feb-18 & 15-Nov-22 & EUR & $30.000 .000,00$ & 0.25 & 15-Nov-18 & $37.500,00$ & 0,16 & 0,16 & $4.925 .629,29$ & $25.074 .370,71$ & $31.342,96$ & $6.157,04$ \\
\hline & & & & & & & & & & & $59.166,67$ & & & & & $51.732,93$ & $7.433,74$ \\
\hline 10869501 & PT. PLN (PERSERO) & ADB-OF & $\begin{array}{l}\text { STRENGTHENING } \\
\text { WEST KALIMANTAN }\end{array}$ & 17-Oct-13 & 04-Apr-14 & 30-Nov-19 & USD & $49.500 .000,00$ & 0,15 & 17-Nov-14 & $66.856,79$ & 0,11 & 0,11 & 5.438.770,57 & $44.061 .229,43$ & $41.307,40$ & $25.549,39$ \\
\hline 10869501 & PT. PLN (PERSERO) & ADB-OF & $\begin{array}{l}\text { STRENGTHENING } \\
\text { WEST KALIMANTAN }\end{array}$ & 17-Oct-13 & 04-Apr-14 & 30-Nov-19 & USD & $49.500 .000,00$ & 0,15 & 15-May-15 & $22.709,32$ & 0,20 & 0,20 & $9.727 .492,74$ & $39.772 .507,26$ & $29.829,38$ & $-7.120,06$ \\
\hline 10869501 & PT. PLN (PERSERO) & ADB-OF & $\begin{array}{l}\text { STRENGTHENING } \\
\text { WEST KALIMANTAN }\end{array}$ & 17-Oct-13 & 04-Apr-14 & 30-Nov-19 & USD & $49.500 .000,00$ & 0,15 & 16-Nov-15 & $21.113,96$ & 0,29 & 0,29 & $14.159 .970,96$ & $35.340 .029,04$ & $26.505,02$ & $-5.391,06$ \\
\hline 10869501 & PT. PLN (PERSERO) & ADB-OF & $\begin{array}{l}\text { STRENGTHENING } \\
\text { WEST KALIMANTAN }\end{array}$ & 17-Oct-13 & 04-Apr-14 & 30-Nov-19 & USD & $49.500 .000,00$ & 0,15 & 16-May-16 & $17.803,64$ & 0,37 & 0,37 & $18.520 .571,15$ & $30.979 .428,85$ & $23.234,57$ & $-5.430,93$ \\
\hline 10869501 & PT. PLN (PERSERO) & ADB-OF & $\begin{array}{l}\text { STRENGTHENING } \\
\text { WEST KALIMANTAN }\end{array}$ & 17-Oct-13 & 04-Apr-14 & 30-Nov-19 & USD & $49.500 .000,00$ & 0,15 & 15 -Nov-16 & $16.825,87$ & 0,46 & 0,46 & $22.905 .130,69$ & $26.594 .869,31$ & $19.946,15$ & $-3.120,28$ \\
\hline 10869501 & PT. PLN (PERSERO) & ADB-OF & $\begin{array}{l}\text { STRENGTHENING } \\
\text { WEST KALIMANTAN } \\
\end{array}$ & 17-Oct-13 & 04-Apr-14 & 30-Nov-19 & USD & $49.500 .000,00$ & 0,15 & 15-May-17 & $15.770,73$ & 0,55 & 0,55 & $27.241 .771,54$ & $22.258 .228,46$ & $16.693,67$ & $-922,94$ \\
\hline 10869501 & PT. PLN (PERSERO) & ADB-OF & $\begin{array}{l}\text { STRENGTHENING } \\
\text { WEST KALIMANTAN }\end{array}$ & 17-Oct-13 & 04-Apr-14 & 30-Nov-19 & USD & $49.500 .000,00$ & 0,15 & 15 -Nov-17 & $15.575,93$ & 0,64 & 0,64 & $31.650 .290,42$ & $17.849 .709,58$ & $13.387,28$ & $2.188,65$ \\
\hline 10869501 & PT. PLN (PERSERO) & ADB-OF & $\begin{array}{l}\text { STRENGTHENING } \\
\text { WEST KALIMANTAN }\end{array}$ & 17-Oct-13 & 04-Apr-14 & 30-Nov-19 & USD & $49.500 .000,00$ & 0,15 & 15-May-18 & $13.604,56$ & 0,73 & 0,73 & $35.986 .931,27$ & $13.513 .068,73$ & $10.134,80$ & $3.469,76$ \\
\hline 10869501 & PT. PLN (PERSERO) & ADB-OF & $\begin{array}{l}\text { STRENGTHENING } \\
\text { WEST KALIMANTAN }\end{array}$ & 17-Oct-13 & 04-Apr-14 & 30-Nov-19 & USD & $49.500 .000,00$ & 0,15 & 15-Nov-18 & $11.810,36$ & 0,82 & 0,82 & $40.395 .450,15$ & $9.104 .549,85$ & $6.828,41$ & $4.981,95$ \\
\hline \multirow[t]{2}{*}{10869501} & PT. PLN (PERSERO) & ADB-OF & $\begin{array}{l}\text { STRENGTHENING } \\
\text { WEST KALIMANTAN }\end{array}$ & 17-Oct-13 & 04-Apr-14 & 30-Nov-19 & USD & $49.500 .000,00$ & 0,15 & 15-May-19 & $8.577,58$ & 0,90 & 0,90 & $44.732 .091,00$ & $4.767 .909,00$ & $3.575,93$ & $5.001,65$ \\
\hline & & & & & & & & & & & $210.648,74$ & & & & & $191.442,63$ & $19.206,11$ \\
\hline
\end{tabular}




\begin{tabular}{|c|c|c|c|c|c|c|c|c|c|c|c|c|c|c|c|c|c|}
\hline \multirow[b]{2}{*}{ REGISTER } & \multirow[b]{2}{*}{$\begin{array}{l}\text { KEMENTERIAN / } \\
\text { LEMBAGA }\end{array}$} & \multirow[b]{2}{*}{$\begin{array}{l}\text { PEMBERI } \\
\text { PINJAMAN }\end{array}$} & \multirow[b]{2}{*}{ NAMA PROYEK } & \multirow[b]{2}{*}{$\begin{array}{l}\text { TANGGAL } \\
\text { LOAN }\end{array}$} & \multirow[b]{2}{*}{$\begin{array}{l}\text { TANGGAL } \\
\text { EFEKTIF }\end{array}$} & \multirow[b]{2}{*}{$\begin{array}{c}\text { BATAS } \\
\text { PENARIKAN } \\
\text { TERAKHIR }\end{array}$} & \multirow[b]{2}{*}{$\begin{array}{l}\text { MATA } \\
\text { UANG }\end{array}$} & \multirow[b]{2}{*}{$\begin{array}{c}\text { NILAI } \\
\text { PINJAMAN }\end{array}$} & \multirow[b]{2}{*}{$\begin{array}{c}\text { COMMIT- } \\
\text { MENT } \\
\text { RATE (\%) }\end{array}$} & \multirow{2}{*}{$\begin{array}{c}\text { TANGGAL } \\
\text { ACUAN } \\
\text { PEMBAYARAN } \\
\text { COMMITMENT } \\
\text { FEE }\end{array}$} & \multirow[b]{2}{*}{$\begin{array}{c}\text { PEMBAYARAN } \\
\text { COMMITMENT } \\
\text { FEE }\end{array}$} & \multirow[b]{2}{*}{ ETR } & \multicolumn{4}{|c|}{ PEMBAYARAN COMMITMENT JIKA PROYEK BERJALAN TEPAT WAKTU } & \multirow{2}{*}{$\begin{array}{c}\text { TAMBAHAN } \\
\text { BIAYA/BIAYA } \\
\text { YANG } \\
\text { SEEARUSNYA } \\
\text { DI EFISIENSI } \\
\text { (COMMITMENT } \\
\text { FEE YANG } \\
\text { DIBAYAR } \\
\text { DIKURANGI } \\
\text { COMMITMENT } \\
\text { FEE JIKA } \\
\text { PROYEK TEPAT } \\
\text { WAKTU) }\end{array}$} \\
\hline & & & & & & & & & & & & & $\begin{array}{l}\text { DR=ETR } \\
(P V=1)\end{array}$ & $\begin{array}{l}\text { KUMULATIF } \\
\text { PENARIKAN }\end{array}$ & $\begin{array}{l}\text { NILAI YANG } \\
\text { BELUM } \\
\text { DITARIK }\end{array}$ & $\begin{array}{c}\text { PEMBAYARAN } \\
\text { COMMITMENT } \\
\text { FEE }\end{array}$ & \\
\hline 1SDVQT1A & KEMHAN & BBVAIT & $\begin{array}{l}\text { Pengadaan Torpedo } \\
\text { A244S Mod. } 3\end{array}$ & 10-Mar-17 & 27-Mar-17 & 30-Jun-20 & EUR & $4.110 .557,50$ & 0,5 & 27-Sep-17 & $10.504,76$ & 0,15 & 0,15 & $635.048,35$ & $3.475 .509,15$ & $8.881,86$ & $1.622,90$ \\
\hline 1SDVQT1A & KEMHAN & BBVAIT & $\begin{array}{l}\text { Pengadaan Torpedo } \\
\text { A244S Mod. } 3\end{array}$ & 10-Mar-17 & 27-Mar-17 & 30-Jun-20 & EUR & $4.110 .557,50$ & 0,5 & 27-Mar-18 & $10.333,48$ & 0,31 & 0,31 & $1.259 .742,64$ & $2.850 .814,86$ & $7.166,63$ & $3.166,85$ \\
\hline 1SDVQT1A & KEMHAN & BBVAIT & $\begin{array}{l}\text { Pengadaan Torpedo } \\
\text { A244S Mod. } 3\end{array}$ & 10-Mar-17 & 27-Mar-17 & 30-Jun-20 & EUR & $4.110 .557,50$ & 0,5 & 27-Sep-18 & $10.504,76$ & 0,46 & 0,46 & 1.894.790,99 & $2.215 .766,51$ & $5.662,51$ & $4.842,25$ \\
\hline \multirow[t]{2}{*}{ 1SDVQT1A } & KEMHAN & BBVAIT & $\begin{array}{l}\text { Pengadaan Torpedo } \\
\text { A244S Mod. } 3\end{array}$ & 10-Mar-17 & 27-Mar-17 & 30-Jun-20 & EUR & $4.110 .557,50$ & 0,5 & 27-Mar-19 & $10.333,48$ & 0,61 & 0,61 & $2.519 .485,29$ & $1.591 .072,21$ & $3.999,78$ & $6.333,70$ \\
\hline & & & & & & & & & & & $\begin{array}{l}41.676,48 \\
\end{array}$ & & & & & $25.710,78$ & $15.965,70$ \\
\hline
\end{tabular}




\section{Lampiran 3}

\section{BAGAN MEKANISME PEMANTAUAN DAN EVALUASI PINJAMAN}

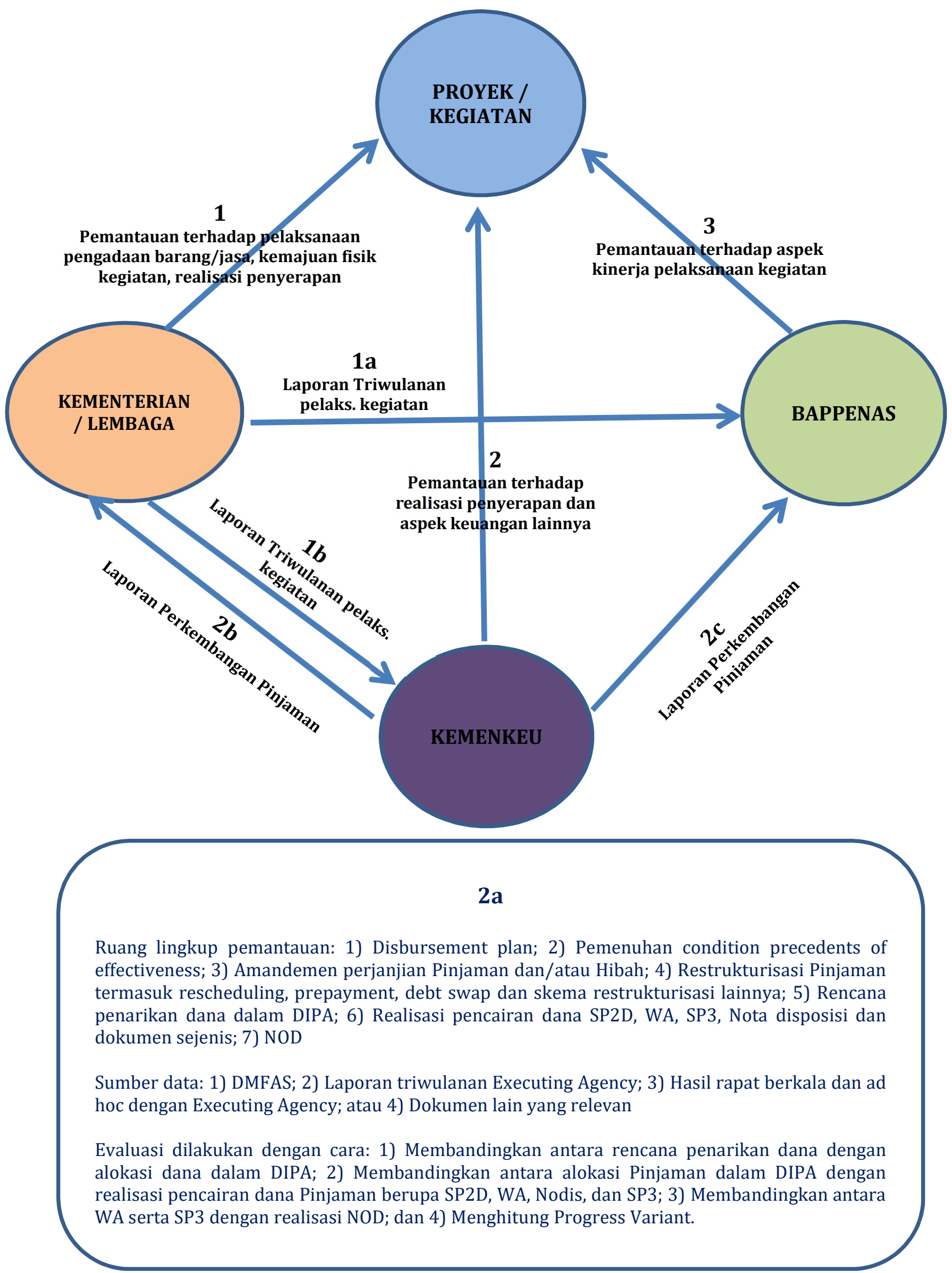

